An Integrated System of Geologic Mapping and Geochemical Sampling by Light Aircraft

By C. L. SAINSBURY, K. J. CURRY, and J. C. HAMILTON

GE OLOGICAL S U R VEY B ULLETIN 1361

$A$ description of a method whereby geologic mapping and geochemical sampling are possible

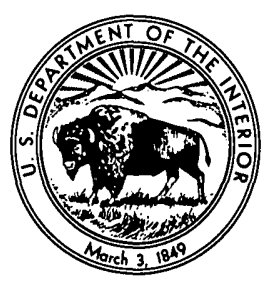




\section{UNITED STATES DEPARTMENT OF THE INTERIOR}

ROGERS C. B. MORTON, Secretary

GEOLOGICAL SURVEY

V. E. McKelvey, Director

Library of Congress catalog-card No. 72-600230

For sale by the Superintendent of Documents, U.S. Government Printing Office Washington, D.C. 20402 - Price: Paper cover -90 cents domestic postpaid or 75 cents GPO Bookstore Stock Number 2401-00265 


\section{CONTENTS}

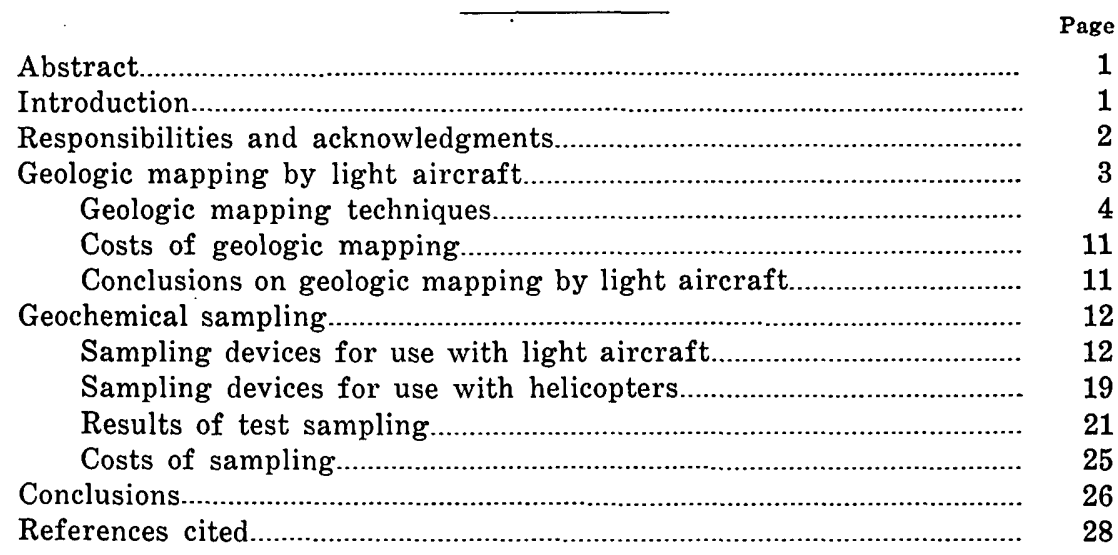

\section{ILLUSTRATIONS}

Plate 1. Geologic map of parts of the Bendeleben A-4, B-3, and B-4 quadrangles, Bendeleben Mountains, Seward Peninsula, Alaska. In pocket

2. Reconnaissance geologic map of part of the Bendeleben 1:250,000 quadrangle, Bendeleben Mountains, Seward Peninsula, Alaska. In pocket

Figure 1. Index map of the Seward Peninsula, Alaska, showing areas mapped and sampled

2-6. Aerial photographs:

2. Western Bendeleben Mountains, illustrating area mapped by light aircraft.

3. Tundra-covered volcanic fields, illustrating the difficulty of photogeologic interpretations............ 6

4. Youthful volcanic cone............................................... 8

5. Intermediate-age volcanic cone.................................. 9

6. Older volcanic cone.............................................. 10

7. Photograph of sampling devices that are dropped from a light aircraft and those that are dropped or lowered from a helicopter.

8. Photographs and diagram of sampling devices that are extended from a light aircraft.

9. Photograph of prototype soil sampler - a device that is dropped from a light aircraft.

10. Photograph of "sticky ball"- a sampling device that is dropped from a light aircraft or helicopter

11. Diagram of device for collecting stream-sediment samples from a helicopter. 


\section{TABLE}

TABLE 1. Metal content of soils, stream sediments, and rock frag-

Page ments collected by light aircraft and of check samples collected by hand. 


\title{
AN INTEGRATED SYSTEM OF GEOLOGIC MAPPING AND GEOCHEMICAL SAMPLING BY LIGHT AIRCRAFT
}

\author{
By C. L. Sainsbury, K. J. Curry, and J. C. Hamilton \\ ABSTRACT
}

Reconnaissance geologic mapping and sampling for geochemical analyses from a light aircraft have been proved feasible. On the Seward Peninsula, Alaska, in areas of fair to good exposures, reconnaissance geologic maps suitable for publication at 1:250,000 scale were prepared at a rate of one 15- by 30-minute quadrangle per day, at a cost, excluding salary, of approximately $\$ 100.00$ per quadrangle. Several of these maps were checked by an impartial observer from a helicopter and were found to be sufficiently accurate for reconnaissance maps. From the air, mineralized structural features, gossans, and potentially mineralized areas are easily seen, plotted, and sampled.

Devices were developed by which samples of soils, sands, stream sediments, rock fragments, and humus can be collected from light aircraft. When such devices are used to identify mapped rock units and to sample potentially mineralized areas, geochemical exploration can be tied firmly to geologic maps made by means of light-aircraft traverses. Geochemical samples can be obtained at a rate of about one sample in 2-3 minutes.

Sampling devices were developed also for use with helicopters. Use of these devices enables collection of geologic and geochemical samples from tree-covered areas, steep slopes, and tree-lined streams, which heretofore could only be sampled by long foot traverses; collection of all types of samples by helicopter is materially speeded up.

\section{INTRODUCTION}

Since 1961, the senior author has been engaged in detailed and regional mapping of the Seward Peninsula, Alaska (fig. 1), for the U.S. Geological Survey. Field support consisted of tracked vehicles (surplus World War II Weasels and Bombardiers), helicopters, and light aircraft owned and piloted by the senior author. Over the years, the light aircraft had been used in progressively more geologically oriented functions, culminating in 1970 in the successful collection from the air of soils, stream sediments, and rock samples. When the sample-collecting devices described in this report are used in conjunction with geologic mapping from light aircraft, dependable reconnaissance geologic maps can be prepared 


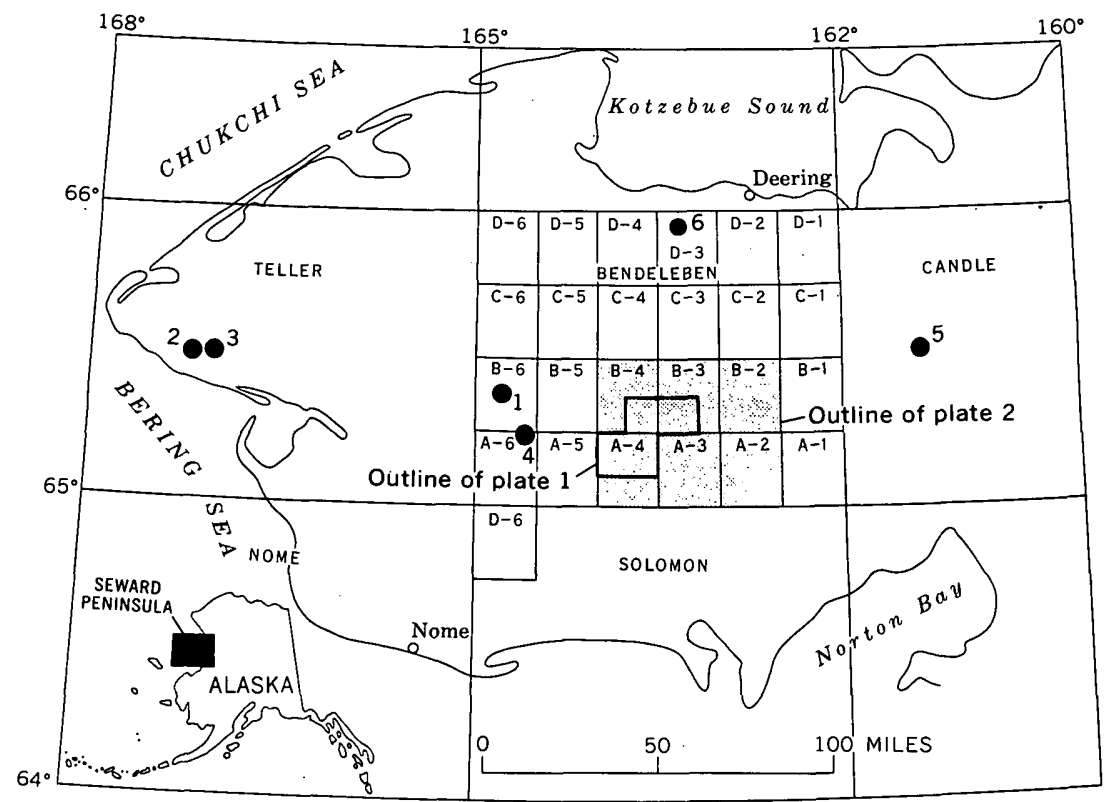

Figure 1. - Index map of the Seward Peninsula, Alaska, showing areas mapped (stippled) and sampled (dots).

at extremely low cost and great speed even in areas where exposures are only moderately good. Moreover, areas of promising mineral potential can be evaluated at very low cost by collection of soil samples, stream sediments, and rock fragments obtained solely from a light aircraft. When devices are adapted to helicopter use, samples can be collected in areas covered by trees, along treelined streams, or from slopes too steep to land upon, thus materially widening the scope of collection, as well as achieving substantial savings over conventional methods. For complete geologic and geochemical reconnaissance surveys, a combined lightaircraft-helicopter project is considered to be the best combination for achievement of the most dependable results at the lowest cost.

The methods and sample-collecting devices described here are under patent application in the United States and in several foreign countries. Development and testing of new devices and techniques are continuing as part of the Geological Survey's research program to improve and speed geologic mapping.

\section{RESPONSIBILITIES AND ACKNOWLEDGMENTS}

Sainsbury developed the techniques, prepared the geologic maps, and collected test samples; Curry performed replicate spectro- 
graphic analyses on duplicate splits of samples; and Hamilton performed spectrographic analyses on check samples, which led to refinement of analytical results. Other analysts are credited in the tables. Harry W. Smedes, geologist, field checked the geologic maps prepared by air traverse; and Daniel R. Shawe, geologist, accompanied Sainsbury during testing of the sand-scoop devices. Mr. Robert Emmons, Alaska State Division of Highways at Nome, stored gasoline, oil, and supplies at his field headquarters north of Nome. All the help received is gratefully acknowledged.

\section{GEOLOGIC MAPPING BY LIGHT AIRCRAFT}

Many geologists occasionally utilize light aircraft in geologic reconnaissance by plotting obvious features on maps or aerial photographs during flight. However, such maps are, at best, crude sketch maps; depiction of rock units and structure must be reasonably complete before a map can be classed as a geologic map. Such depiction has been found to be possible and realistic if the light aircraft is used by the geologist-pilot ${ }^{1}$ to carry out wellplanned geologic traverses by air in the same manner as traverses are made by foot, horseback, or tracked vehicle.

To prepare a dependable geologic map by air traverse, the geologist-pilot must possess the ability to recognize various rock types from the air (which requires much field experience) and must be capable of safe flying at low levels and speeds in mountainous terrain - abilities which come only from experience in such flying. The ability to land on hillslopes and on river bars and terraces is essential when ground traverses need to be made.

In preparing the maps accompanying this report, a Super Cub with a 135-horsepower engine was used; this engine was preferred to the 150-horsepower model because of the added 1.5 hours of flying time with only 36-gallon (U.S.) fuel tanks. The aircraft. was equipped with tundra tires (fig. $8 C$ ) for landing on rough fields and hillslopes. In addition, a hole 5 inches square was cut in the floor forward of the rear seat, and an opening was cut in the fabric directly beneath this hole. The opening in the fabric was covered with a removable standard inspection plate. These openings allowed sampling devices to be extended from the aircraft. No other special modifications were needed because no work was done above an altitude of 10,000 feet, where performance loss becomes noticeable. If much work above 10,000 feet were to have been done, a more powerful engine would have been preferable. Ten extra gallons of gasoline, a tire pump, emergency food, shel-

\footnotetext{
1The senior author believes that for optimum efficiency the geologist should be the pilot; however, a geologist and a pilot operating as a team probably can develop considerable proficiency in mapping, and certainly in sampling.
} 
ter, and sleeping gear, as well as a crash-locator beacon, were carried at all times for safety. The weight of these items in the baggage compartment facilitated landings on short strips by acting as ballast to prevent the aircraft from tipping on its nose on rough ground when brakes had to be applied forcefully immediately upon landing.

To illustrate the mapping method, reference will be made to plates 1 and 2, which are reconnaissance geologic majps made entirely by aerial traverse in a light aircraft without the use of sampling devices and with only a few landings for ground traverses. Mapping was carried out at the rate of about one 15- by 30-minute quadrangle (about $250 \mathrm{sq} \mathrm{mi}$ ) a day. Maps were field checked by helicopter by an impartial observer, who found the maps "remarkably accurate" (H. W. Smedes, written commun., 1970). Figures 2 and 3 illustrate the diverse types of terrain which were mapped.

\section{GEOLOGIC MAPPING TECHNIQUES}

Successful geologic mapping from the air entails planning of traverses and objectives exactly as for mapping on the ground. Planned traverses are needed to preclude the natural tendency to wander from one interesting geologic feature to another, which results in a series of disconnected observations and plots. Inasmuch as geologic contacts are the most important single feature on geologic maps, traverses should be oriented toward the mapping of contacts wherever possible. To illustrate, the traverses used to compile the maps inclucied in this report are outlined briefly. Mapping was done directly upon $1: 63,360$-scale topographic maps while the aircraft was in flight. The data were transferred later to the $1: 250,000$-scale map.

As illustrated by parts of plate 1 , fault displacement can be determined from the offset of recognizable beds on opposite sides of a fault. Approximate strikes and dips of units and features such as dragfolds even a few feet in amplitude can be seen. In fact, geologic data too detailed to retain on the $1: 250,000$ compilation can be plotted on the $1: 63,360$-scale map.

Mapping generally proceeded from simpler to more difficult areas, so cumulative experience was valuable. The first aerial traverse was flown over the carbonate belt which crosses the Bendeleben Mountains obliquely and extends across three 1:63,360 quadrangles. This area was mapped in about 8 hours' flying time. The contacts were traced without difficulty on the topographic maps by flying the aircraft at reduced speed (using flaps) at approximately 150 feet above the terrain. From this altitude, bedding, foliation, minor fold axes, dikes, and small outliers of 


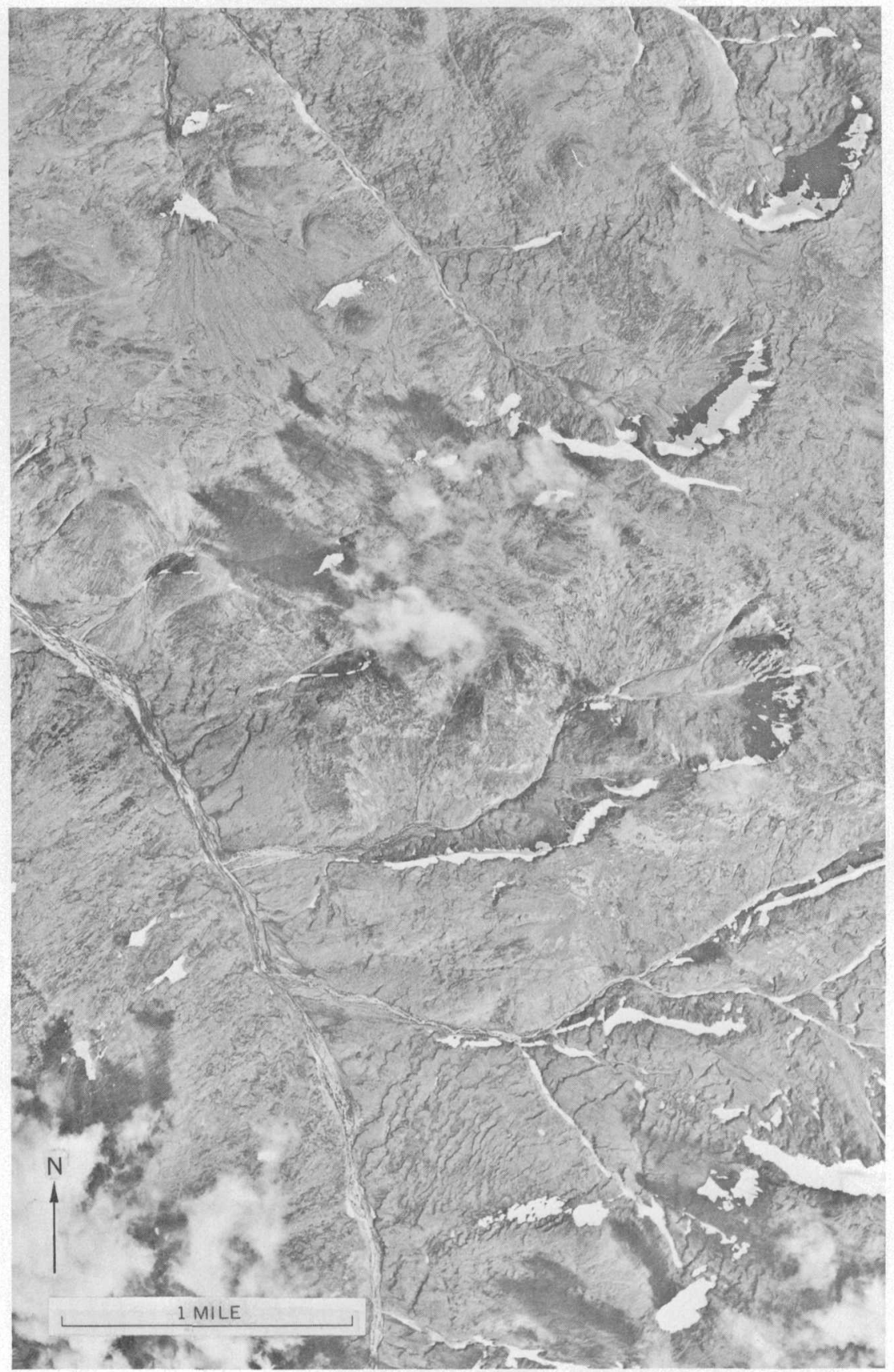

Figure 2. - Aerial photograph of the western Bendeleben Mountains, illustrating the area mapped by light aircraft. Area is in the western part of the Bendeleben B-4 quadrangle. 


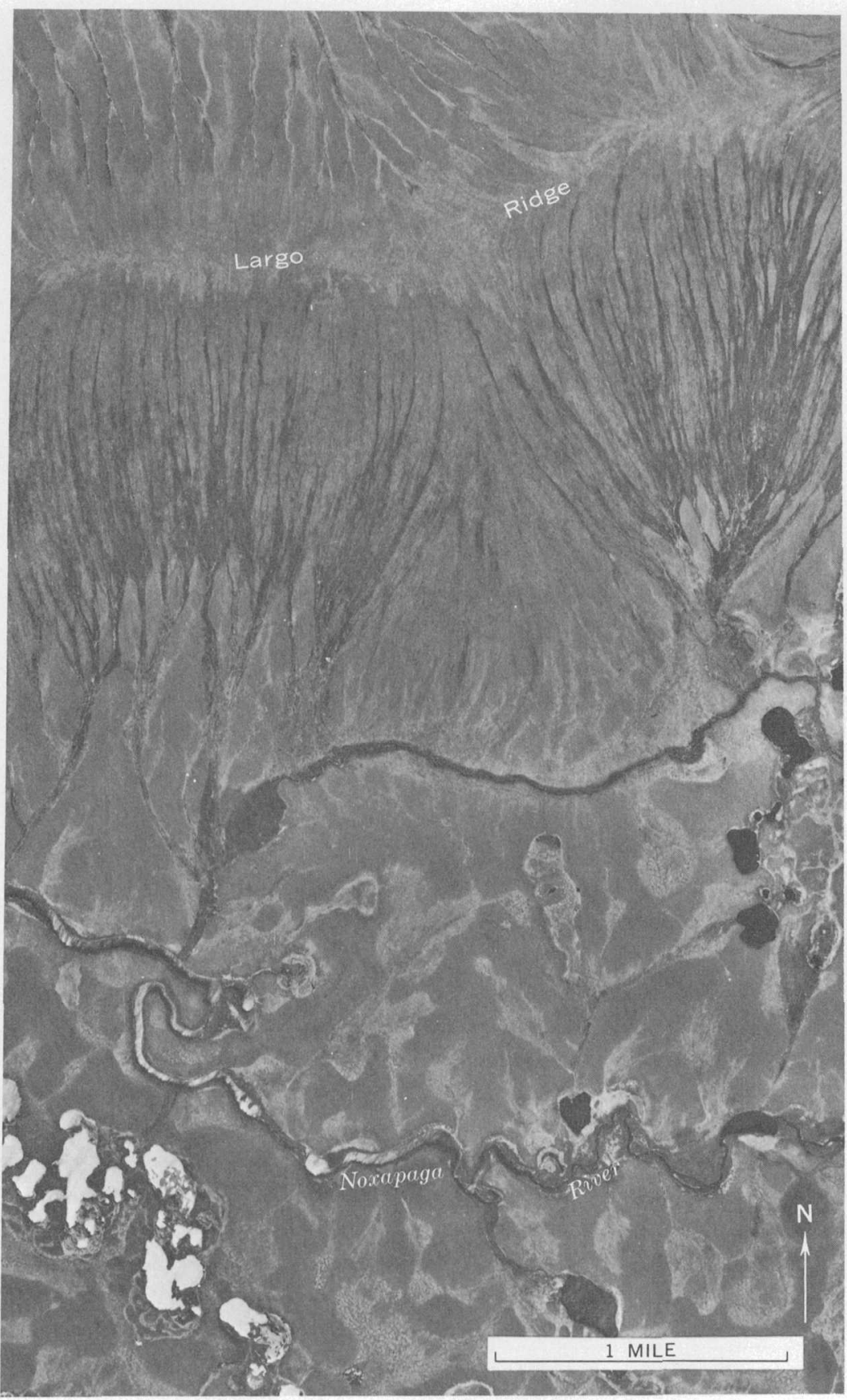

FIgURE 3.- Aerial photograph of tundra-covered volcanic fields of Imuruk Lake lowlands, illustrating the difficulty of photogeologic interpretations in area mapped. Area is in the Bendeleben $\mathrm{C}-4$ quadrangle; it is not shown on plate 2 . 
the granitic rocks could be seen. Although the marbles are contorted, the contacts could be plotted very accurately on steep slopes. For plotting contacts by altimeter readings on gentle slopes, the correct altitude was achieved by flying the aircraft at normal cruise speed across a point of land having a spot elevation shown on the topographic map, the altimeter was set, and the aircraft was then flown by the slope to plot the contact. This method probably results in greater accuracy than does plotting the contact on the ground after a long foot traverse, for the time lag between setting the altimeter and plotting the contact is at most a few minutes. The effects of pressure changes thus are minimized.

The very large granitic body that occupies much of the Bendeleben A-2, B-2, and B-3 quadrangles was next mapped throughout an area of about 500 square miles. Fault zones were plotted in detail, and a large area of "altered granite" was outlined, as were numerous altered areas along faults. Though no samples were taken from the air, subsequent work by helicopter showed that the "altered granite" was indeed an altered fluorite-bearing granitic rock (H. W. Smedes, oral commun., 1970). During mapping of the granite, a landing was made on the shore of Kuzitrin Lake (B-3 quadrangle), and a traverse was made on foot to secure samples of the granite for chemical and spectrographic analyses, isotopic studies, and age dating. Without the use of the "sticky ball" collecting device, developed later, the drawing of a sharp contact between the granitic rock and a belt of high-rank gneisses along the southwest margin of the granite proved to be impractical. By use of the collecting devices described later, this contact could have been mapped, but the mapping would have required more time in the air.

Next, a day was spent in mapping the gneiss-mantled granitic dome in the Bendeleben A-4 quadrangle (pl. 1) and the ironstained migmatitic area in the $\mathrm{A}-4$ and $\mathrm{B}-4$ quadrangles, an area of about 200 square miles. The attitude of the gneissic banding in the gneiss dome could be plotted when the aircraft was flown with the wingtip approximately 20 feet from the steep slopes (which sounds much worse than it really is). Again, the contact between the granitic core and the gneiss mantle was not plotted, inasmuch as no samples were collected. However, all the features of greatest interest to the economic geologist were readily plotted; for example, the numerous altered iron-stained dikes, the large area of altered and stained Precambrian metamorphic rocks, and the larger of the intrusive bodies. The system of altered dikes that trends north-northeast in the western part of the A-4 quadrangle was plotted, and several old prospect pits were noted. The area was sufficiently interesting that a landing was made on a terrace 


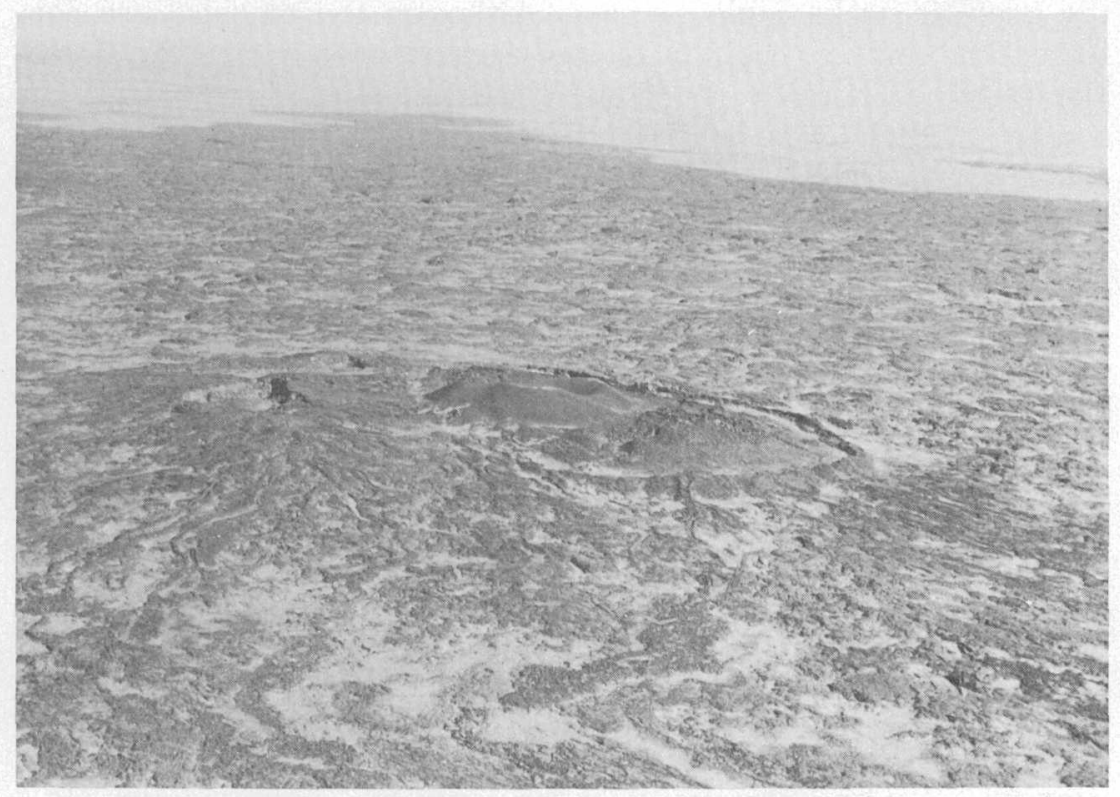

FIGURE 4. - Youthful cone and its associated volcanic field, Imuruk Basin.

above the Niukluk River, and a 2-hour ground traverse completed. Samples of mineralized dikes showed that argentiferous galena occurs where the altered dikes cut thin marbles in the Precambrian metamorphic rocks and occurs disseminated in the Precambrian rocks over a wide area.

Next, the great expanse of tundra-covered flats in the Bendeleben B-3, B-4, B-5, C-2, C-3, C-4, and C-5 quadrangles was mapped in 3 days of flying at the rate of about 400 square miles per day. Recent flows were readily mapped from the air; these could have been mapped equally well from aerial photographs, but flows of intermediate age would have been more difficult to map by photographs. The older flows have been completely broken down and are now covered by tundra. An aerial photograph of an area of older flows (fig. 3) shows no hint of bedrock. However, by slow flight at low levels, sufficient geologic observations were made to be certain that vast expanses of tundra and muskeg-covered ground are underlain by older volcanic rocks.

The following specific types of observations were made about the tundra-covered flats: (1) Frost-heaved and frost-cracked basaltic boulders are exposed in the tundra almost everywhere vesicular cavities can be observed in many; (2) almost all small sluggish streams have lava boulders in their beds; locally, volcanic 
rocks are exposed where small falls have formed over edges of lava flows; (3) ubiquitous dark sand in the stream bars shows that volcanic rocks are the principal source rocks; (4) thaw lakes are rare on the older flows but extremely abundant on gravel lowlands outside the flows; occasionally, volcanic rocks can be observed in wave-cut banks of thaw lakes; (5) the volcanic flows are characterized by youthful, intermediate, and old cones; the older cones in the area mapped are recognizable with certainty only by observation from low levels, which usually discloses abundant frost-heaved boulders of volcanic rocks, or ash in gullies or in slumped areas (figs. 4-6). The numerous old cones, which on aerial photographs cannot be told from pingos, are corroborative evidence that the surrounding tundra-covered areas are underlain by volcanic rocks.

A long foot traverse from the aircraft, which was landed on a lakeshore, disclosed only volcanic rocks and float of volcanic rocks and confirmed the observations made in flight.

To illustrate the many details that can be observed and plotted by aerial traverse, the contact between volcanic rocks and a terminal moraine shown in the B-4 quadrangle (pl. 2) was mapped;

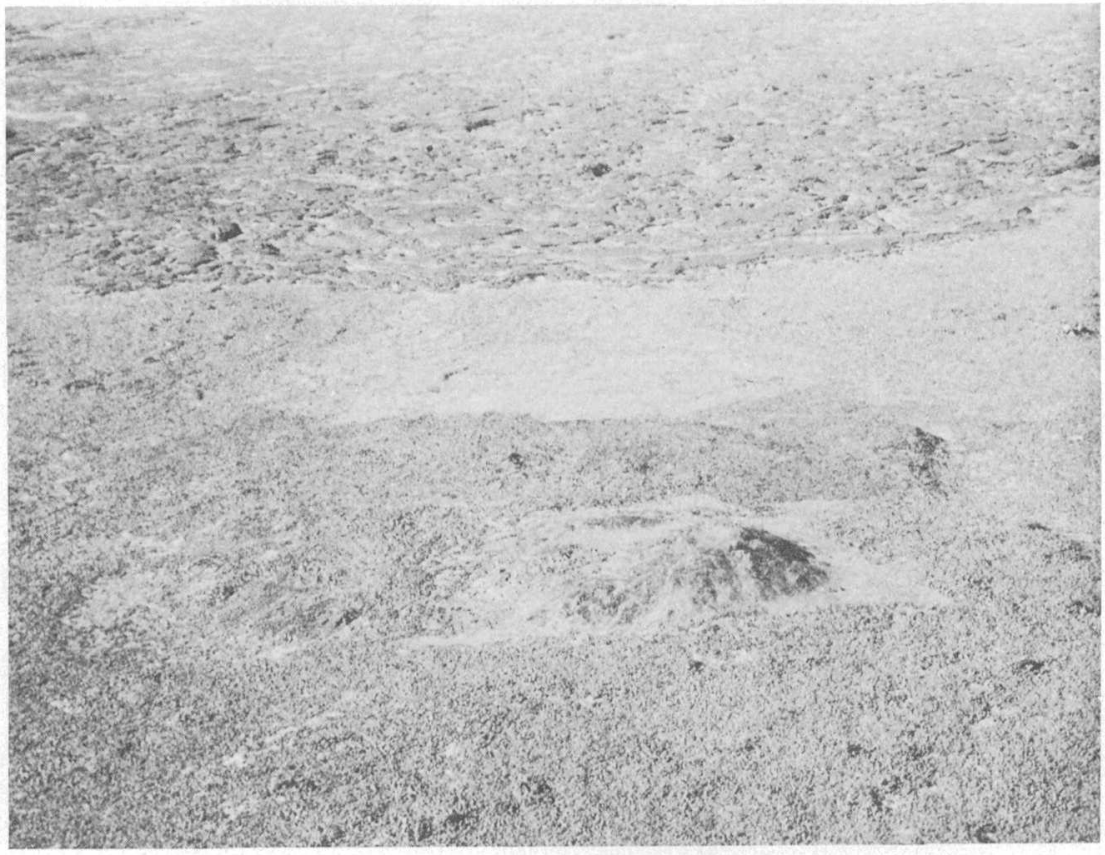

Figure 5. - Intermediate-age cone with its volcanic fields reduced to rubble; Imuruk Basin. 


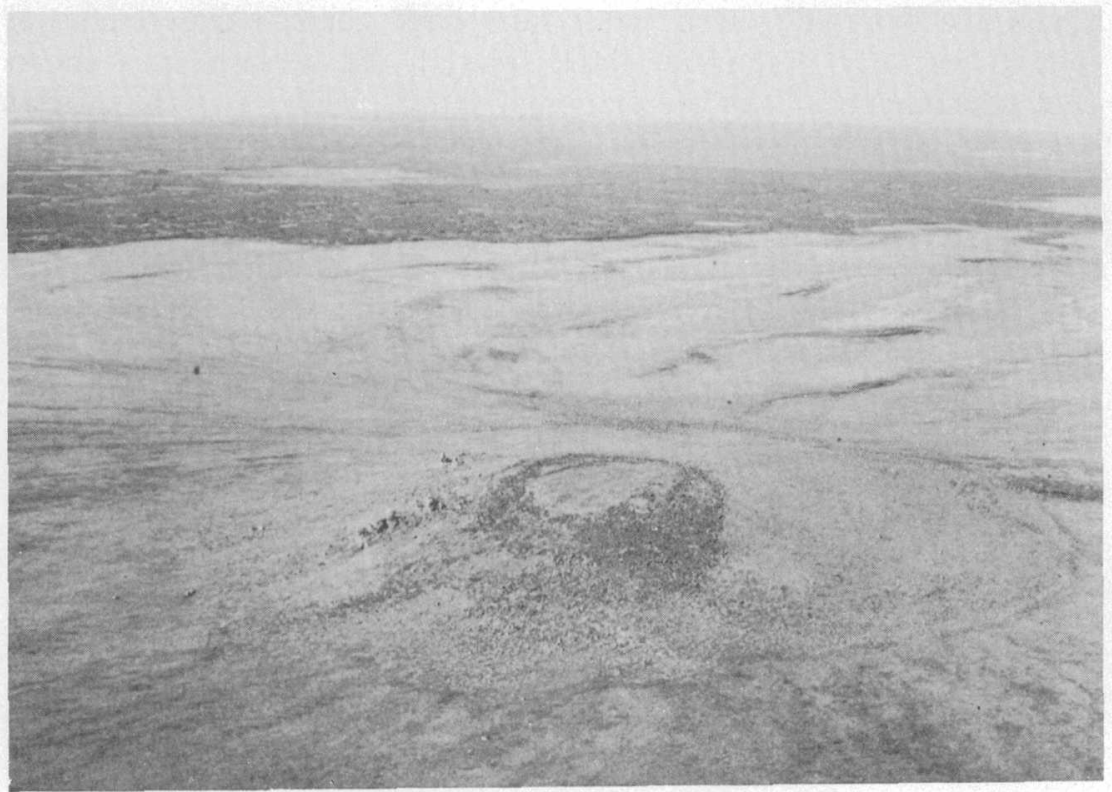

FIGURE 6. - Older cone almost obliterated by erosion, with its volcanic field completely covered by tundra; Imuruk Basin.

from the air it was plainly seen that lava had flowed behind the terminal moraine. In the C-3 quadrangle (not included on pl. 2) a volcanic cone capping a granite hill was mapped from the air, the major bedrock expanse being mapped as granite. A recent geologic map of the area shows the entire hill to be volcanic (Herreid, 1966). Subsequent check by helicopter showed that the relations mapped by air are the correct ones.

To illustrate the advantage of being able to tie geochemical surveys to bedrock geology as mapped from the air, the work of Asher (1970) was integrated with the aerial traverse mapping. In the A-5 quadrangle, extensive geochemical sampling of stream sediments by Asher demonstrated widespread anomalies of copper, lead, zinc, cobalt, and molybdenum. The anomalies extend eastward into the A-4 quadrangle (pl. 1). Asher did not map the area geologically, but the reconnaissance maps prepared by light aircraft show that the drainage basins of these streams contain numerous altered and iron-stained dikes, some mineralized by lead, zinc, silver, and copper. The mineralized dikes probably account for the widespread geochemical anomalies found by Asher. In short, more and more geologic detail can be added by additional flying time and by foot traverses from the aircraft, the cutoff-point being determined entirely by the discretion of the geologist-pilot. A point 
of diminishing return is soon reached, however, in reconnaissance mapping.

\section{COSTS OF GEOLOGIC MAPPING}

The preparation of reconnaissance maps used to compile plate 2 required about 6 hours of flying time per 15- by 30-minute quadrangle. Most parts of 10 quadrangles, totaling about 2,500 square miles, were mapped (not all quadrangles are shown on pl. 2), and aircraft costs were about $\$ 780.00$. Field per diem costs were $\$ 10$ a day, or $\$ 100.00$. These costs are based upon reimbursement by the U.S. Geological Survey of $\$ 13.20$ per hour for use of the Super Cub; however, rented Super Cubs in Alaska cost approximately $\$ 40.00$ per hour with pilot. Photoreduction of the field sheets was approximately $\$ 25.00$, and direct tracing to the final $1: 250,000$ scale sheet took approximately 6 days. In addition to the mapping, a geologic report could have been written covering salient features of the geology and pointing out the areas of potential mineral deposits. The economic data indicated on plate 2 would require several man-weeks, at the least, to evaluate on the ground.

With application of the sampling devices and techniques which were developed after the area was mapped, the geologic maps could have been refined, and many samples could have been obtained from most of the altered zones. Several more foot traverses would have been valuable. Such refinement of data would have doubled the time and expense for mapping each quadrangle.

During June 1971, the airborne methods described here were combined with numerous foot traverses from spike camps placed by light aircraft and from the landed aircraft. One quadrangle was mapped for inch-to-the-mile publication with about 25 hours of flying time and about 20 man-days of foot traverse. The area is structurally complex, involving overthrusting and complex faulting. This quadrangle, the Solomon D-6, Seward Peninsula, will be checked in about 4 hours of helicopter time. A similar area on the Seward Peninsula mapped by the senior author using normal ground methods required three full summers.

\section{CONCLUSIONS ON GEOLOGIC MAPPING BY LIGHT AIRCRAFT}

Mapping by aerial traverse is rapid, cheap, reasonably accurate, and safe. Geologic elements of interest are quickly and easily spotted, enabling the geologist to concentrate on these areas. By using aircraft mapping techniques, large areas can be mapped at a cost so reasonable that companies can afford preparation of reconnaissance geologic maps of large areas for their own use. When combined with the geochemical sampling techniques next described, rapid coverage of large, unexplored, and unmapped areas of the world should be possible. 
The drawbacks of the method are that an experienced geologistpilot is required, that rock units with similar weathering characteristics cannot always be distinguished unless samples are secured, which is not always possible, and that potentially mineralized areas cannot always be evaluated to the desired degree unless a helicopter is employed. However, the advantages far outweigh the disadvantages.

\section{GEOCHEMICAL SAMPLING}

Samples of rock collected from the air are used to identify rock units being mapped; they can also be analyzed along with soil and sediment samples to prepare geochemical maps. Although the light aircraft was used to collect the samples discussed in this report, the methods are also applicable to helicopter surveys, especially when samples are needed in places where the helicopter cannot land. Such places include steep slopes or surfaces covered by obstructions, such as trees, brush, boulders, and manzanita. The methods offer advantages over recent techniques employed by industry, such as carrying a geologist in a sling beneath a helicopter while he samples tree tops, as done recently in Montana (Hansford T. Shacklette, oral commun., 1970), or lowering a man on a cable from a hovering helicopter, as done recently in Canada (Peter O. Sandvik, oral commun., 1971).

\section{SAMPLING DEVICES FOR USE WITH LIGHT AIRCRAFT}

Devices made to collect samples while the aircraft remains in flight were developed and tested in late 1970. Three basic types of devices were employed. Two of these types were attached to a nylon parachute cord and dropped or impelled from the aircraft or helicopter and then retrieved by the cord (figs. $7 A$ and $B, 9$, $10)$. Devices of the third type were attached to a flexible rod made of jointed and threaded sections that is extended from the aircraft to encounter the material to be sampled as the aircraft is flown over it (fig. 8). Minor modifications have been made in some devices for simplification and ease of construction and repair. Recent models are pictured in figure 7. Droppable devices are most useful in sampling wet or dry soils, wet sands or stream sediments where tree cover is sparse or lacking, and rock fragments on smooth slopes or in talus cones or alluvial fans. The relatively crude prototype model used to collect soil samples listed in table 1 is shown in figure 9. All the devices are described briefly.

The soil-sampling device pictured in figure $7 B$ consists of a cylindrical steel body into which is drilled or milled a hole approximately 2.2 inches $(5.59 \mathrm{~cm})$ long and 0.75 inch $(1.91 \mathrm{~cm})$ in diameter, or a hole just large enough to accept snugly any standard-size polyethylene sample holder. A 1/4-inch-diameter slant 


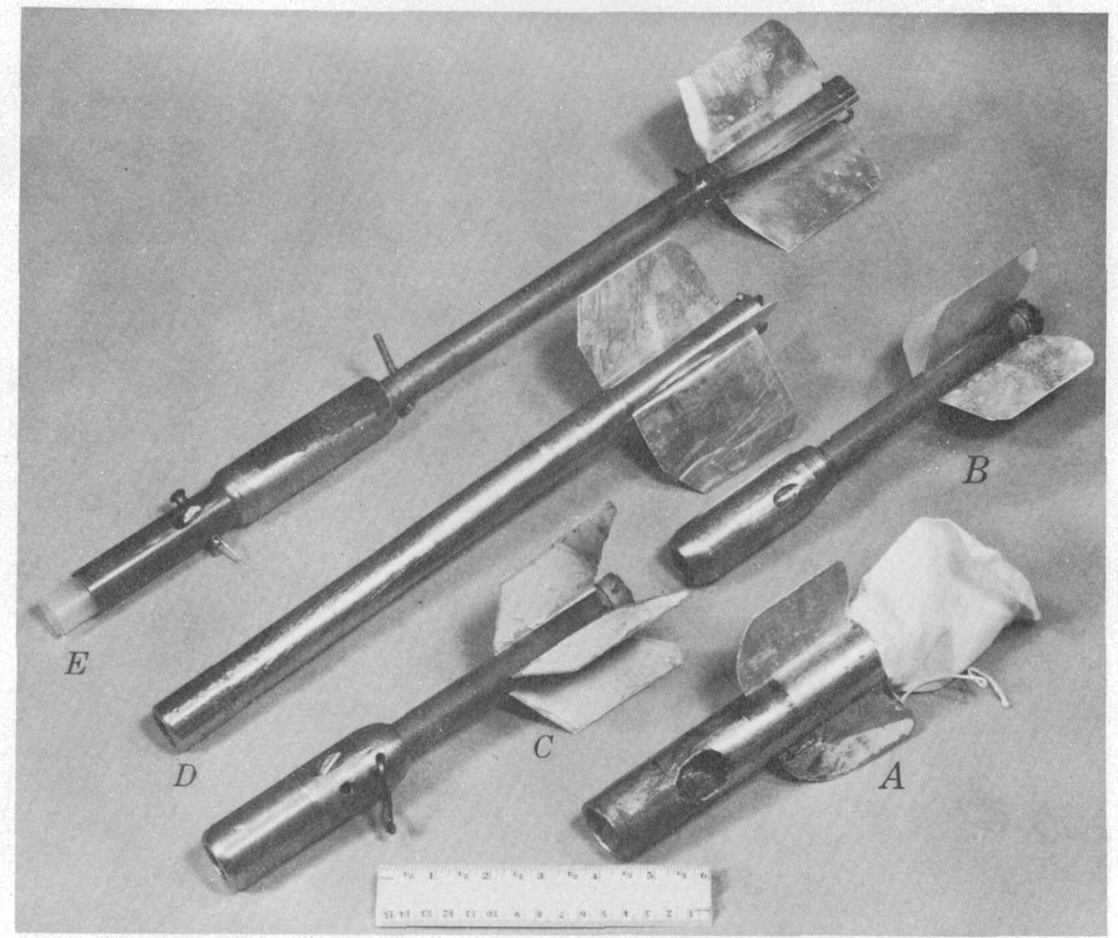

FIGURE 7. - Sampling devices that are dropped from a light aircraft $(A-C)$ and those that are dropped or lowered from a helicopter ( $D$ and $E$ ). $A$, Bottom view of sand and dry-soil sampler. $B$ and $C$, Bottom and side views, respectively, of soil sampler. $D$, Device for sampling soils beneath tundra or at deeper horizons. E, Device for sampling surface soils or wet sands. Upper scale is in inches.

hole is drilled forward from the rear part of the body so that a rod can be pushed against the base of the sample holder to eject it. A small hole leading backward through the base of the sample holder chamber allows air to eject rearward on impact. A set of guiding fins is inserted into a steel tube sawed on two sides by bending the fins at a $90^{\circ}$ angle, inserting them into the sawed slots, and locking them by welding a ring over the rear of the tube to prevent spreading. The tube fits snugly over a milled extension of the steel nose and is locked by a bolt through a hole drilled through the tube and the milled extension. A welded towing ring passes through a hole in the steel body, which is forward of the aerodynamic center and slightly rearward of the gravity center of the sampling device. This arrangement of sample holder and holes is similar in all other droppable devices here discussed that have fins and a sample holder. 


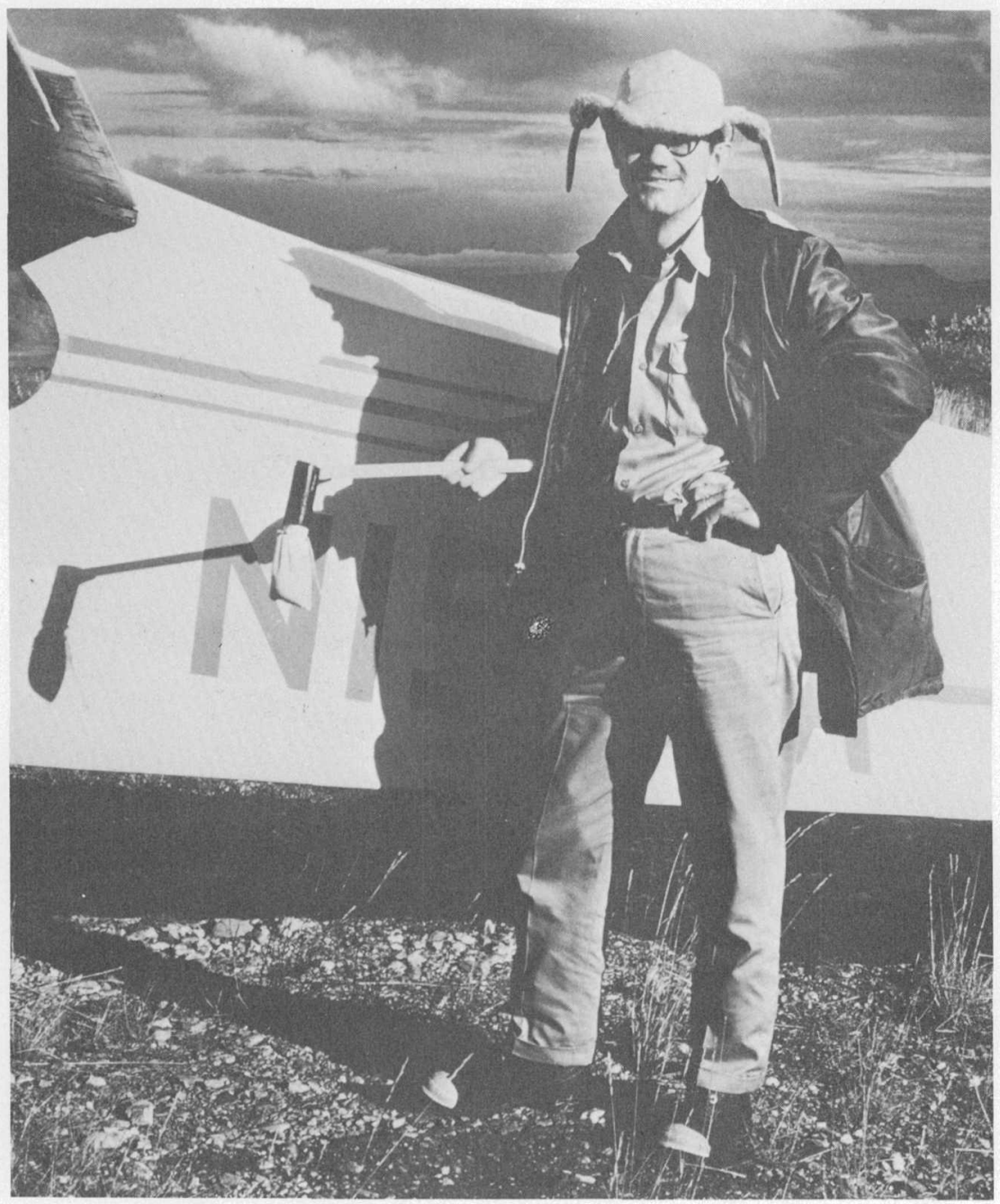

$A$

Figure 8. - Sampling devices that are extended from a light aircraft. $A$, Scoop for sampling sand or loose soil. $B$, Basket scoop for recovering loose rock fragments. $C$, Prototype scoop device with filled sample bag in retracted position beneath the belly of the Super Cub. Note large tundra tire.

In operation, one end of a nylon parachute cord is fastened to a battery-operated winch which is securely fastened to a strength member in the airplane, and the other end is attached to the towing ring on the sampler. A nylon parachute cord has a breaking strength of about 400 pounds and is sufficiently elastic to prevent shock to the airframe of the aircraft. It will break if the sampling 
device lodges, without detectable effect on the airplane (personal observation). The geologist-pilot approaches the area to be sampled into the wind, if possible, at reduced airspeed and about 15-20 feet above ground level, and with the sampler extended slightly through the hole in the belly of the aircraft (or if the geologist is alone, through the side window, which is properly reinforced at
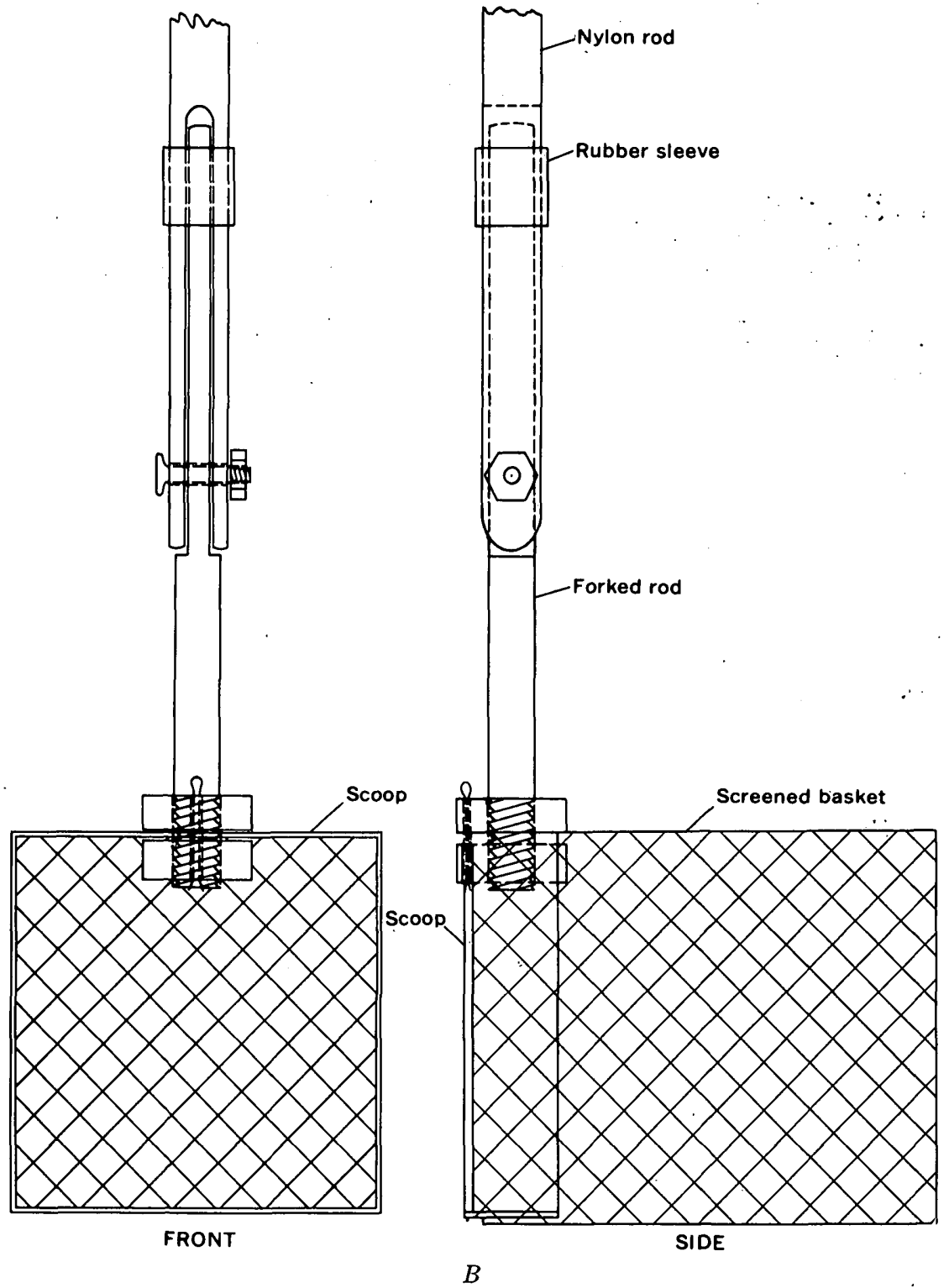

FIgURE 8. - Continued. See facing page for explanation. 


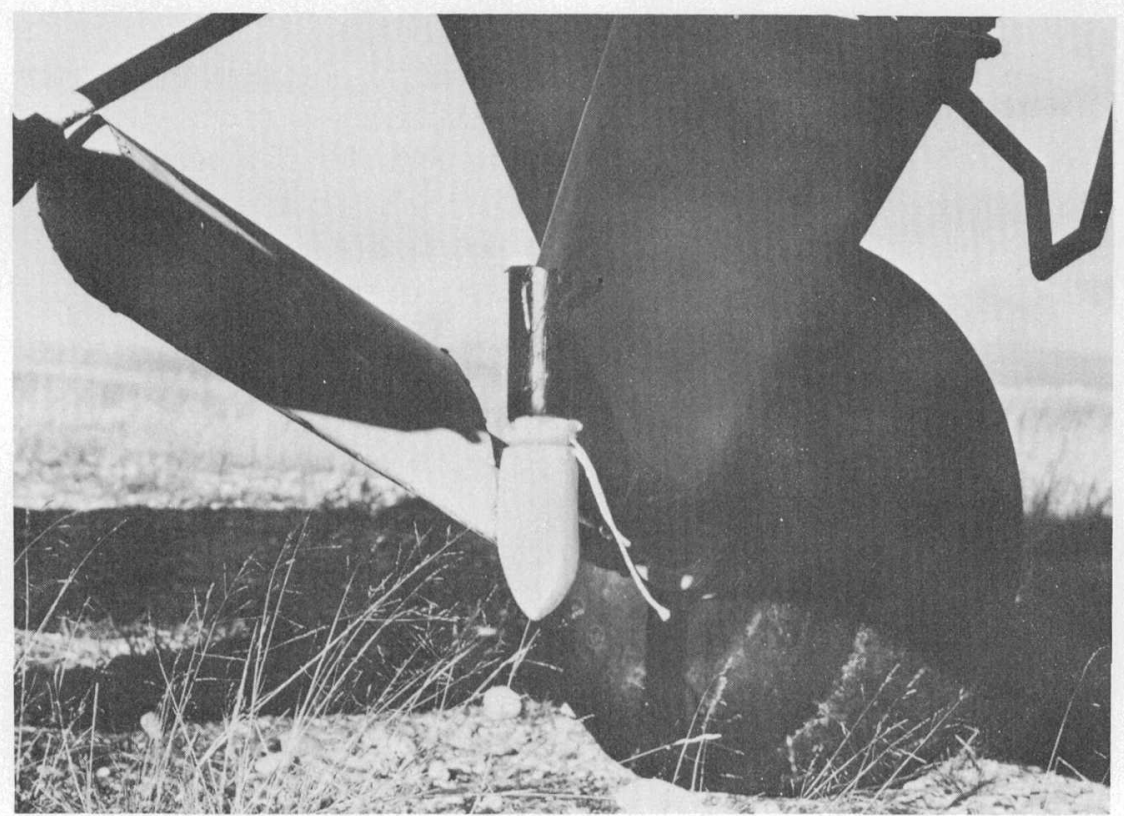

C

Figure 8. - Continued. See p. 14 for explanation.

the rear to take the shock of recovery). At the proper point, the sampler is dropped, and about 100 feet of cord allowed to strip out with it. The sampler impacts into the material to be sampled, generally at a shallow angle, fills the sample container, and is retrieved by the nylon cord. No wet soil samples were lost during retrieval in initial tests, although tests to collect dry desert soils with the same devices proved that a retainer must be employed to prevent loss of the sample. The sample holder is pushed out and placed in a numbered sample bag, and the device is ready for reuse with a new sample holder. Although the senior author was warned of the difficulty to be expected from a "wildly swinging bomb" behind the aircraft, no such difficulty was encountered, for the aerodynamically stable sampler always came smoothly back to the aircraft, even when retrieved jerkily by hand. If the aircraft is too close to the ground (about 2-3 ft) when the sampler is dropped, the tailwheel may strike the sampler if the sampler bounces. Also, if too short a piece of nylon cord is used (about $30-40 \mathrm{ft}$ ), the elasticity of the cord is sufficient to jerk the sampler forward with such velocity as to overtake the aircraft, which obviously is dangerous. With cord length exceeding 75 feet, there is no danger. 


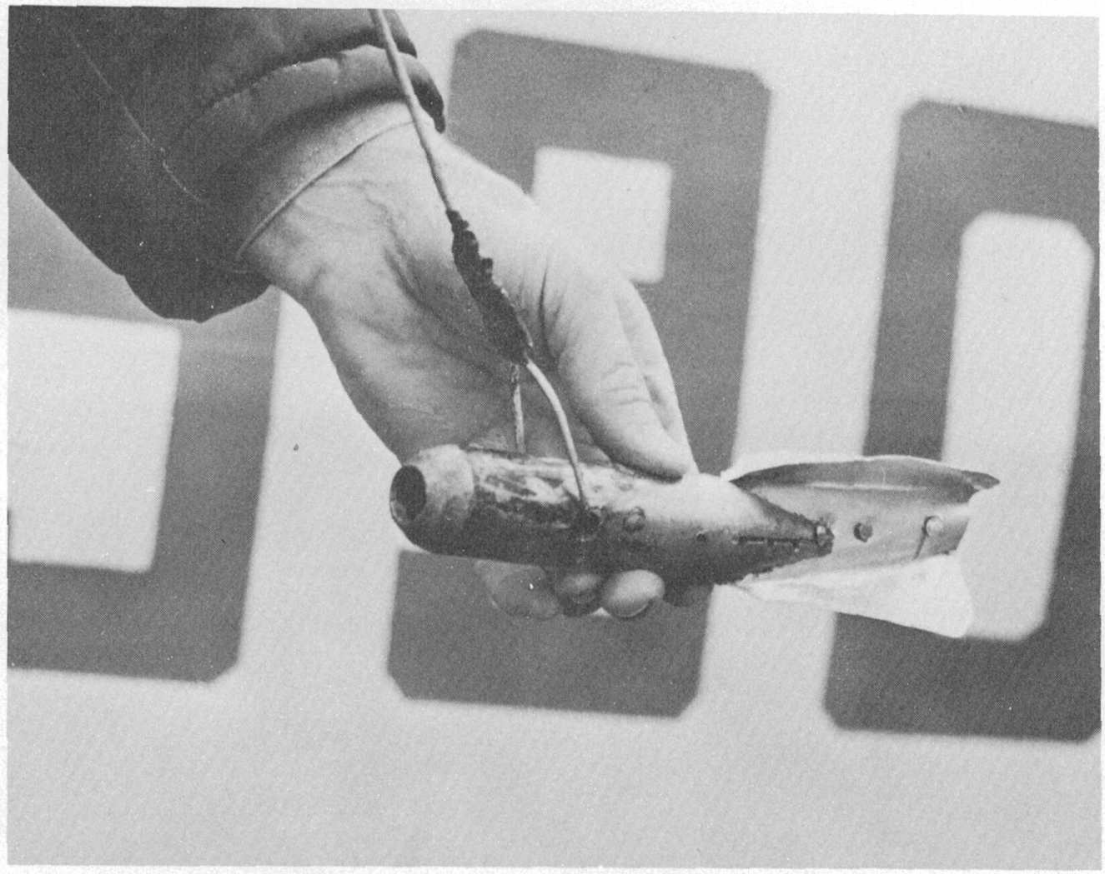

Figure 9. - Prototype soil sampler - a device that is dropped from a light aircraft. Also see figure $7 B$ and $C$.

All the devices which are dropped from the light aircraft are used in similar manner and with similar precautions.

The sampling device pictured in figure $7 \mathrm{~A}$ consists of a finned open-ended tube with a towing ring (towing ring not shown). A sand sample bag is tied to the body rearward of the fins with strings or elastic bands passing around the tube in a recessed hollow or in front of a knurled lip. An opening near the bottom of the sampler has a scoop welded to it ( scoop not affixed in model photographed). When dropped into dry sand, dry soil, or sediment, the device fills on impact, and with recovery, the unconsolidated material passes backward into the sample bag. For very dry sands or soils, the sample in the container is shielded from wind by a slotted rubber shield that fits into a recessed depression in the nose of the sampler. This allows material to pass inward on impact but prevents wind loss of the dry material in the holder.

A third type of droppable device, which is most useful for recovering rock fragments, is shown in figure 10. It consists of a ball of aluminum attached to a nylon cord and covered with about 1 inch of tenacious adhesive (aircraft putty was used initially). When dropped onto small loose rock fragments, pieces of rock are 


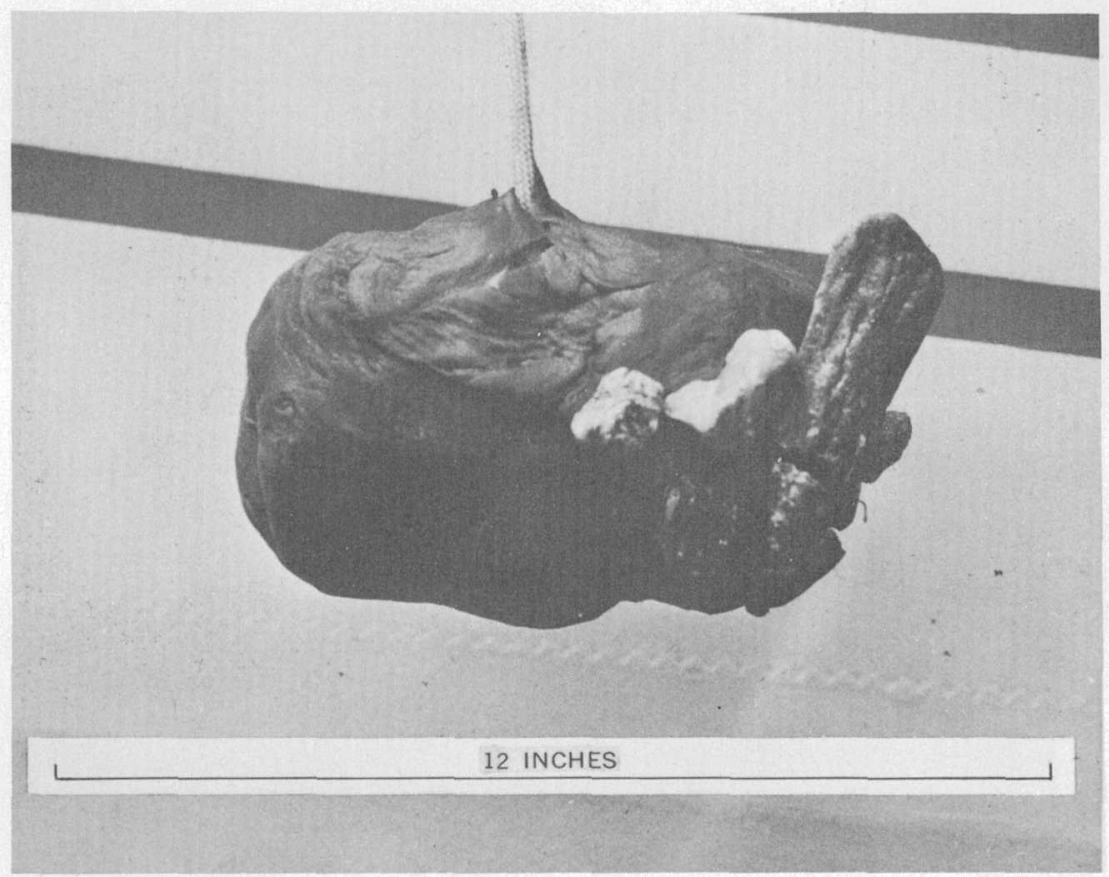

Figure 10. - "Sticky ball"- a sampling device that is dropped from a light aircraft or helicopter. Shows rock fragments attached to the ball.

embedded in the adhesive and are recovered in the aircraft. If the ball is of steel, it is too heavy, and the adhesive is so thinned on impact that rock fragments do not imbed - hence, the use of the aluminum ball. If the fragments recovered are to be analyzed, an inert adhesive is used. Fragments collected are extremely useful for identifying rock units during geologic mapping by aerial traverse, as well as for geochemical analyses.

Sampling devices that remain attached to the aircraft are shown in figure $8 A$ and $B$; they are especially useful in sampling beach sands, dunes, and stream sediments in broad streams where the aircraft is not endangered by trees or brush. Their use almost requires two people. In operation, threaded nylon rods with the sampler attached are joined together in the aircraft as the sampler is extended beneath the belly of the aircraft. When the sampler extends about 2 feet beneath wheel level, the upper part of the jointed rod is rested against the rear of the pilot's seat, and the pilot approaches the area to be sampled, into the wind, at approximately 15-20 miles per hour above stall speed (to maintain climbout capability), as if to land. At the proper instant, the scoop is made to contact the loose sand gently, the sample bag is filled 
immediately, and the aircraft is climbed while the man in the rear seat retrieves the sampler, marks the bag, and extends the sampler again. Figure $8 C$ shows the prototype scoop sampler with a filled sample bag partly retracted beneath the belly of the aircraft.

It was the senior author's experience when collecting stream sediments with Mr. Shawe on the Kuzitrin River, Alaska, that the shock of contact of the sampler was so slight that he could not tell for certain when the sampler dug into sand - Mr. Shawe merely stated "contact," and the aircraft was climbed, usually with a full sample bag.

Figure $8 B$ shows a drawing of a sample device useful in collecting loose rock fragments from smonth slopes, or stream gravels. It is similar in operating principle to the sand scoop just described, except that it consists of a screened basket rather than a sample bag. Shocks are absorbed by the jointed nylon rods, as well as by the rubber sleeve over the forked rod which forms the lower part of the rod assembly. Samples are collected by flying the aircraft close to the ground and allowing the basket to collect fragments of rock as the basket scrapes the ground lightly.

A variation of the scoop basket would be useful in geobotanical sampling if a set of steel "knives" were placed across the opening. With such a device, samples of the upper parts of vegetation, including trees, could be collected by flying the aircraft close and allowing the cutters and basket to drag through the uppermost twigs, leaves, or small branches of the material to be sampled.

\section{SAMPLING DEVICES FOR USE WITH HELICOPTERS}

Inasmuch as a helicopter is indispensable in modern exploration and mapping, sampling devices have been designed for use with the helicopter (fig. $7 D$ and $E$ ). The "sticky ball" described above also is useful in helicopter work. Soil samplers (fig. $7 D$ and $E$ ) consist of a finned tube attached to a milled steel body into whose forward end is inserted a polyethylene holder. These are dropped from a hovering helicopter and penetrate to a depth sufficient to fill the holder, then they are retrieved by a nylon cord attached to the rear of the sampler. Depth of penetration is controlled by the height from which the sampler is dropped, the length of the sample-collecting tube, the shape of the blunt end, and the weight of the milled steel body. For sampling through humus, a thickwalled hollow tube with fins and a constant-diameter bore (polished to facilitate cleaning) is used for deep penetration. An enlarged nose section insures that the sampler will free easily from the ground by driving a hole slightly larger than the sampler body (fig. $7 D$ ). A larger device, with a shielded nose has been developed to sample to depths of as much as 2 feet (not pictured). 


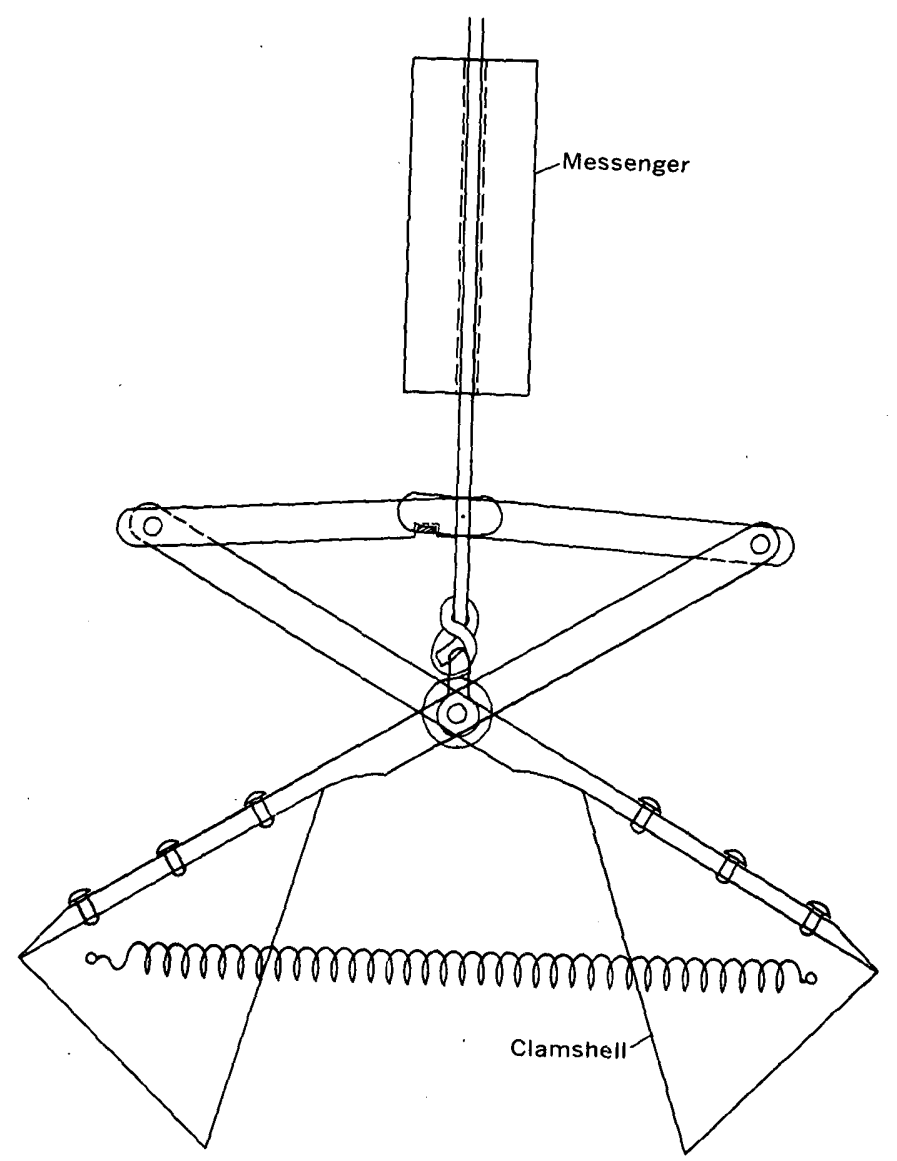

Figure 11. - Device for collecting stream-sediment samples from a helicopter; side view.

For soil surveys by helicopter, devices of different weight and sample chamber size can be utilized. Samples can be collected from areas where trees, cactus, brush, or mesquite and chaparral will not allow a helicopter to land. Even on clear slopes, the devices can be dropped and retrieved from a hovering helicopter in considerably less time than it takes to land, secure a sample, and take off. Steep slopes, where landings would be impossible, can be sampled easily. Samplers are being developed to collect samples from areas of muskeg, from soils below tundra, and from deeper soils in weathered areas or where thin caliche or wind-blown dust armors the upper soil profile.

For sampling sediments or alluvium along streams, where landings are impossible or impractical because of tree and brush cover, a delayed-action clamshell is useful (fig. 11). The helicopter is 
hovered, the device is lowered onto the sand, and a messenger is dropped to trigger the buckets, which are closed by spring action. Other samplers are being designed for special purposes, such as a device which is activated by electricity, and another which will employ the auger principle and will be capable of penetrating caliche or baked soils to sample deep horizons.

\section{RESULTS OF TEST SAMPLING}

The results of field tests of sampling devices to collect soil, rock fragments, sands, and other sediments are shown in table 1. Rock and soil samples were collected by the senior author alone; sediment samples were collected with Shawe's help.

Several areas were tested briefly (fig. 1) by devices dropped from the Super Cub. Approximately 80 samples were collected; additional collecting was prevented by extremely bad weather at the end of the field season and by the start late in the season. Only enough of the analyses are reported in table 1 to illustrate the geochemical anomalies obtained over various areas. Areas tested are located by dot and number on the index map, figure 1 . All the soils and sediments were damp when collected. Areas sampled are:

1. Dahl Creek area west of the Kougarok River, Bendeleben B-6 quadrangle, where placer gold is associated with altered slate that contains numerous angular quartz fragments.

2. Rapid River area, Teller B-5 quadrangle, where berylliumfluorite deposits are exposed (Sainsbury, 1969).

3. Lost River area, Teller B-5 quadrangle, where extensive tintungsten-beryllium and fluorite deposits exist and where detailed soil sampling had been done previously on the ground (Sainsbury and others, 1968).

4. Kuzitrin River area, Bendeleben A-6 quadrangle, where broad river bars were amenable to sampling by extension scoop.

5. Quartz Creek area, eastern Seward Peninsula, where large geochemical anomalies were reported associated with altered volcanic rocks (Miller and Elliott, 1969), on the basis of ground and helicopter traverses.

6. Hannum Creek area, Bendeleben D-3 quadrangle, where a mineralized fault zone crosses a drainage divide along which bulldozer trenches were dug through the tundra to expose frozen soil (Herreid, 1966). Only three samples were collected by aerial methods in this area, from one trench along Hannum Creek.

Samples were sent to Curry for treatment and analysis. Each sample was air-dried and screened into plus-40-mesh and minus40-mesh fractions. Each fraction was powdered, and a split was 
TABLE 1. - Metal content of soils, stream sediments, and rock fragments

[All contents are in parts per million except where otherwise indicated. $L$, detected, but below

that was collected by hand near sample collected by air. Analyses are semiquantitative

Curry (1) and J. C. Hamilton (2) ]

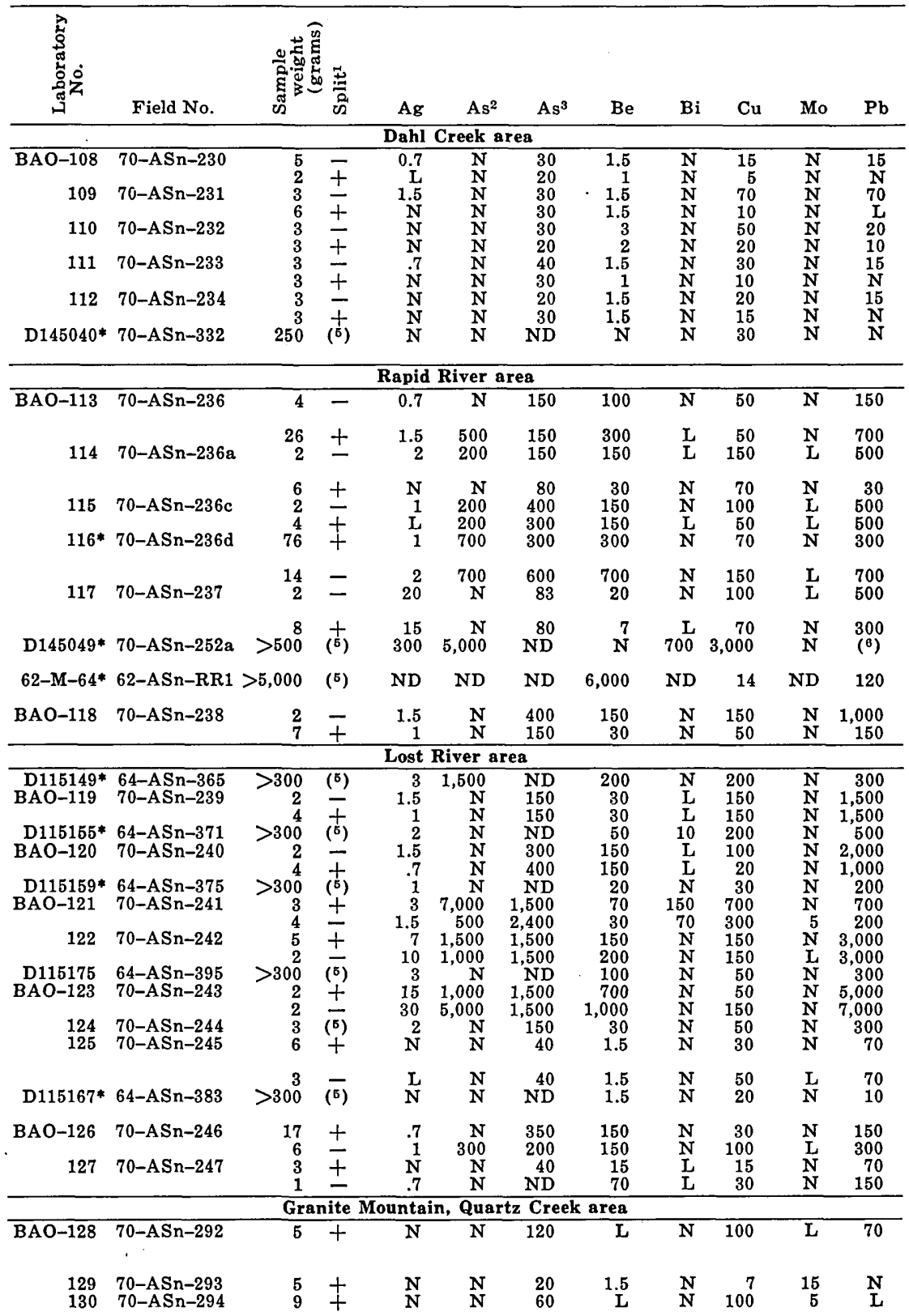

See footnotes at end of table. 
collected by light aircraft and of check samples collected by hand

limit of reading: $N$, below detection limit; ND, not determined; asterisk (*), check sample spectrographic except where otherwise noted. Semiquantitative spectrographic analyses by $\mathrm{K}$. J.

\begin{tabular}{|c|c|c|c|c|c|c|c|c|}
\hline $\mathrm{Sb}$ & Sn & W & $\mathrm{Zn}^{2}$ & $\mathrm{Zn}^{3}$ & $\mathrm{Hg}^{4}$ & Sample type & Remarks & 4 \\
\hline \multicolumn{9}{|c|}{ Dahl Creek area - Continued } \\
\hline $\begin{array}{l}\mathbf{N} \\
N \\
N \\
N \\
N \\
N \\
N \\
N \\
N \\
N \\
N\end{array}$ & $\begin{array}{l}15 \\
N \\
15 \\
N \\
N \\
N \\
N \\
N \\
N \\
N \\
N\end{array}$ & $\begin{array}{l}\mathbf{N} \\
\mathbf{N} \\
\mathbf{N} \\
\mathbf{N} \\
\mathbf{N} \\
\mathbf{N} \\
\mathbf{N} \\
\mathbf{N} \\
\mathbf{N} \\
\mathbf{N} \\
\mathbf{N}\end{array}$ & $\begin{array}{l}\mathbf{N} \\
\mathbf{N} \\
\mathbf{N} \\
\mathbf{N} \\
\mathbf{N} \\
\mathbf{N} \\
\mathbf{N} \\
\mathbf{N} \\
\mathbf{N} \\
\mathbf{N}\end{array}$ & $\begin{array}{r}29 \\
33 \\
200 \\
55 \\
44 \\
65 \\
30 \\
25 \\
300 \\
95 \\
\text { ND }\end{array}$ & $\begin{array}{l}0.24 \\
.2 \\
.7 \\
.5 \\
.2 \\
.08 \\
.16 \\
.08 \\
.26 \\
.06 \\
\text { ND }\end{array}$ & 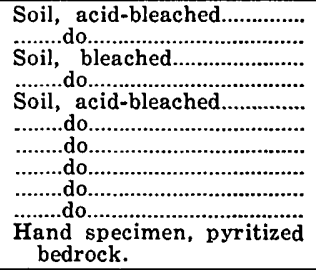 & 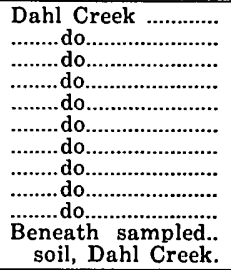 & $\begin{array}{l}2 \\
1 \\
2 \\
1 \\
2 \\
1 \\
2 \\
1 \\
2 \\
2 \\
1 \\
2\end{array}$ \\
\hline \multicolumn{9}{|c|}{ Rapid River area - Continued } \\
\hline $\mathbf{N}$ & 70 & $\mathbf{N}$ & 200 & 430 & 1.0 & 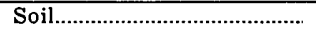 & \multirow{8}{*}{ 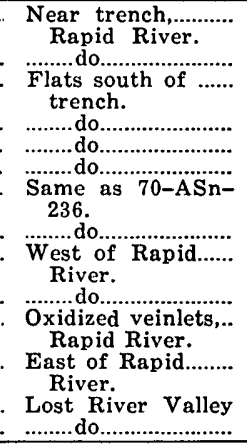 } & 2 \\
\hline$\stackrel{\mathrm{L}}{\mathrm{N}}$ & $\begin{array}{r}150 \\
30\end{array}$ & $\underset{\mathrm{L}}{\mathrm{L}}$ & $\underset{L}{200}$ & $\begin{array}{l}440 \\
220\end{array}$ & $\begin{array}{l}1.0 \\
.65\end{array}$ & …...do do & & 1 \\
\hline $\begin{array}{l}\mathrm{N} \\
\mathrm{L} \\
\mathrm{L}\end{array}$ & $\begin{array}{r}10 \\
150 \\
50\end{array}$ & $\begin{array}{l}\mathrm{N} \\
\mathrm{L} \\
\mathrm{L}\end{array}$ & $\begin{array}{r}\mathrm{N} \\
200 \\
\mathrm{~L}\end{array}$ & $\begin{array}{r}53 \\
360 \\
280\end{array}$ & $\begin{array}{l}.16 \\
.45 \\
.35\end{array}$ & 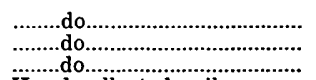 & & $\begin{array}{l}2 \\
1 \\
1\end{array}$ \\
\hline $\mathrm{L}$ & 150 & $\mathbf{N}$ & 300 & 460 & .5 & Hand-collected soil..................... & & 1 \\
\hline$\stackrel{\mathrm{L}}{\mathrm{N}}$ & $\begin{array}{l}150 \\
150\end{array}$ & $\stackrel{L}{N}$ & $\begin{array}{r}300 \\
\mathrm{~N}\end{array}$ & $\begin{array}{r}500 \\
80\end{array}$ & 1.6 & 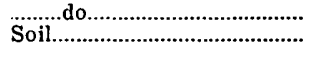 & & $\begin{array}{l}1 \\
1\end{array}$ \\
\hline$\underset{150}{N}$ & $\begin{array}{r}15 \\
3,000\end{array}$ & $\underset{\mathbf{N}}{\mathbf{L}}$ & $\begin{array}{r}\mathrm{N} \\
5,000\end{array}$ & $\begin{array}{r}55 \\
\mathrm{ND}\end{array}$ & $\stackrel{9}{\text { ND }}$ & 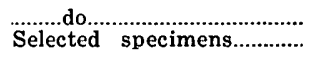 & & $\begin{array}{l}1 \\
2\end{array}$ \\
\hline ND & 120 & ND & ND & ND & ND & Random chip, ore................... & & 2 \\
\hline $\begin{array}{l}\mathbf{N} \\
\mathbf{N}\end{array}$ & $\begin{array}{l}700 \\
500 \\
\end{array}$ & $\stackrel{\mathrm{L}}{\mathrm{N}}$ & $\begin{array}{l}700 \\
300 \\
\end{array}$ & $\begin{array}{l}720 \\
530 \\
\end{array}$ & $\begin{array}{l}.12 \\
.05 \\
\end{array}$ & Soil. do & & $\begin{array}{l}1 \\
2 \\
\end{array}$ \\
\hline \multicolumn{9}{|c|}{ Lost River area - Continued } \\
\hline $\begin{array}{l}\mathbf{N} \\
\mathbf{N} \\
\mathbf{N}\end{array}$ & $\begin{array}{l}300 \\
300 \\
300\end{array}$ & $\begin{array}{l}N \\
L \\
L\end{array}$ & $\begin{array}{r}1,500 \\
300 \\
300\end{array}$ & $\begin{array}{l}\text { ND } \\
340 \\
350\end{array}$ & $\begin{array}{l}\text { ND } \\
.18 \\
.04\end{array}$ & 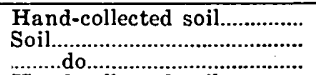 & 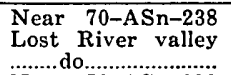 & $\begin{array}{l}2 \\
1 \\
1\end{array}$ \\
\hline $\begin{array}{l}\mathbf{N} \\
\mathbf{N} \\
\mathbf{N}\end{array}$ & $\begin{array}{l}200 \\
700 \\
500\end{array}$ & $\begin{array}{l}\mathbf{N} \\
\mathbf{N} \\
\mathbf{N}\end{array}$ & $\begin{array}{r}1,500 \\
700 \\
300\end{array}$ & $\begin{array}{l}\text { ND } \\
900 \\
370\end{array}$ & $\begin{array}{l}\text { ND } \\
1.0 \\
.07\end{array}$ & $\begin{array}{l}\text { Hand-collected soil. } \\
\text { Soil }\end{array}$ & $\begin{array}{l}\text { Near } 70-\text { ASn-239 } \\
\text { Lost River valley } \\
\text {.....do }\end{array}$ & $\begin{array}{l}2 \\
1 \\
1\end{array}$ \\
\hline $\begin{array}{l}\mathbf{N} \\
\mathbf{L}\end{array}$ & $\begin{array}{r}100 \\
>1000\end{array}$ & $\begin{array}{l}\mathbf{N} \\
70\end{array}$ & 300 & ND & ND & $\begin{array}{l}\text { Hand-collected soil....................... } \\
\text { Stream sediment }\end{array}$ & $\begin{array}{l}\text { Near } 70-\mathrm{ASn}-240 \\
\text { Lost River Valley }\end{array}$ & 2 \\
\hline $\mathrm{L}$ & 500 & L & $\begin{array}{r}1,500 \\
700\end{array}$ & $\begin{array}{l}1,400 \\
1,750\end{array}$ & .11 & Soil.......... & 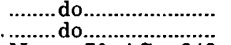 & $\begin{array}{l}2 \\
1\end{array}$ \\
\hline $\begin{array}{l}N \\
\mathrm{~L}\end{array}$ & $\begin{array}{l}150 \\
500 \\
700\end{array}$ & $\begin{array}{c}N \\
\mathrm{~L} \\
50\end{array}$ & $\begin{array}{r}700 \\
700 \\
2000\end{array}$ & $\begin{array}{r}\text { ND } \\
1,400\end{array}$ & $\begin{array}{r}\text { ND } \\
.11 \\
.16\end{array}$ & 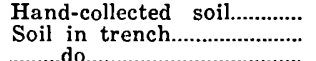 & $\begin{array}{l}\text { Near } 70-\text { ASn-242 } \\
\text { Lost River valley }\end{array}$ & $\begin{array}{l}2 \\
1 \\
1\end{array}$ \\
\hline$\stackrel{N}{N}$ & $\begin{array}{r}150 \\
15\end{array}$ & N & $\begin{array}{r}500 \\
\mathbf{N}\end{array}$ & $\begin{array}{r}1,600 \\
250\end{array}$ & $\begin{array}{l}.16 \\
.18 \\
.16\end{array}$ & 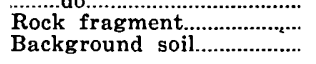 & $\begin{array}{l}\text { Bessie-Maple dump } \\
\text { Mouth of Esch...... }\end{array}$ & $\begin{array}{l}1 \\
2\end{array}$ \\
\hline$\stackrel{N}{N}$ & $\begin{array}{r}20 \\
0\end{array}$ & $\stackrel{N}{N}$ & $\stackrel{\mathbf{L}}{\mathbf{N}}$ & $\begin{array}{l}230 \\
\mathrm{ND}\end{array}$ & $\begin{array}{l}.16 \\
\text { ND }\end{array}$ & Hand-col & 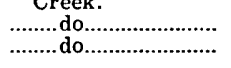 & $\begin{array}{l}1 \\
2\end{array}$ \\
\hline $\begin{array}{l}\mathbf{N} \\
\mathbf{L} \\
\mathbf{N} \\
\mathbf{N}\end{array}$ & $\begin{array}{r}70 \\
70 \\
70 \\
200 \\
\end{array}$ & $\begin{array}{l}\mathbf{N} \\
\mathbf{N} \\
\mathbf{N} \\
\mathbf{N}\end{array}$ & $\begin{array}{r}\mathrm{L} \\
300 \\
\mathrm{~N} \\
\mathrm{~L} \\
\end{array}$ & $\begin{array}{r}310 \\
290 \\
44 \\
\text { ND }\end{array}$ & $\begin{array}{l}.55 \\
.55 \\
.08 \\
.26\end{array}$ & 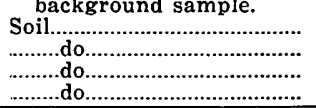 & 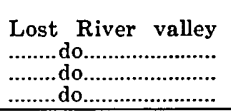 & $\begin{array}{l}2 \\
1 \\
1 \\
1\end{array}$ \\
\hline \multicolumn{9}{|c|}{ Granite Mountain, Quartz Creek area - Continued } \\
\hline $\mathbf{N}$ & $\mathbf{N}$ & $\mathbf{N}$ & 200 & ND & .26 & Soil......................................... & $\begin{array}{l}\text { West fork Buck } \\
\text { Creek, Granite } \\
\text { Mountain area. }\end{array}$ & 1 \\
\hline$\stackrel{N}{N}$ & $\stackrel{N}{N}$ & $\begin{array}{l}N \\
N\end{array}$ & $\mathbf{N}$ & $\begin{array}{l}\text { ND } \\
\text { ND }\end{array}$ & $\begin{array}{l}.55 \\
.35\end{array}$ & 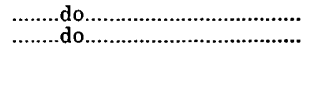 & $\begin{array}{l}\text { Ridge between....... } \\
\text { Buck Creek and } \\
\text { Quartz Creek. }\end{array}$ & $\begin{array}{l}1 \\
1\end{array}$ \\
\hline
\end{tabular}


TABLE 1. - Metal content of soils, stream sediments, and rock fragments

\begin{tabular}{|c|c|c|c|c|c|c|c|c|c|c|c|}
\hline 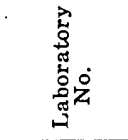 & Field No. & 资 & & $\mathrm{Ag}$ & $\mathrm{As}^{2}$ & $\mathrm{As}^{3}$ & $\mathrm{Be}$ & $\mathbf{B i}$ & $\mathrm{Cu}$ & Mo & $\mathrm{Pb}$ \\
\hline \multicolumn{12}{|c|}{ Granite Mountain, Quartz Creek area - Continued } \\
\hline 131 & 70-ASn-295 & 6 & + & $\mathbf{N}$ & $\mathrm{N}$ & 10 & $\mathbf{N}$ & $\mathbf{N}$ & 70 & 7 & $\mathrm{~L}$ \\
\hline $\begin{array}{l}132 \\
133\end{array}$ & $\begin{array}{l}70-\mathrm{ASn}-296 \\
70-\mathrm{ASn}-297\end{array}$ & $\begin{array}{l}6 \\
3\end{array}$ & \pm & $\stackrel{\mathrm{N}}{\mathrm{N}}$ & $\stackrel{N}{N}$ & $\begin{array}{l}10 \\
10\end{array}$ & $\stackrel{N}{N}$ & $\stackrel{N}{N}$ & $\begin{array}{r}7 \\
15\end{array}$ & $\begin{array}{r}30 \\
\mathrm{~L}\end{array}$ & $\begin{array}{l}\mathrm{L} \\
\mathrm{L}\end{array}$ \\
\hline D145033* & $70-\mathrm{ASn}-300$ & $>300$ & (5) & $\mathrm{N}$ & $\mathbf{N}$ & ND & $\mathrm{N}$ & $\mathrm{N}$ & 50 & $\mathbf{N}$ & 300 \\
\hline $\begin{array}{r}036^{*} \\
\mathrm{BAO}-134^{*}\end{array}$ & $\begin{array}{l}70-\mathrm{ASn}-300 \mathrm{c} \\
70-\mathrm{ASn}-301-1\end{array}$ & $\begin{array}{r}>300 \\
204\end{array}$ & $\begin{array}{l}(5) \\
(5)\end{array}$ & $\stackrel{N}{N}$ & $\stackrel{\mathrm{N}}{\mathrm{N}}$ & $\begin{array}{r}\text { ND } \\
30\end{array}$ & $\stackrel{N}{N}$ & $\stackrel{N}{N}$ & $\begin{array}{r}15 \\
100\end{array}$ & $\begin{array}{l}\mathbf{N} \\
\mathbf{L}\end{array}$ & $\stackrel{\mathrm{L}}{\mathrm{N}}$ \\
\hline
\end{tabular}

\begin{tabular}{|c|c|c|c|c|c|c|c|c|c|c|c|}
\hline \multicolumn{12}{|c|}{ Kuzitrin River area } \\
\hline BAO-135 & $70-\mathrm{ASn}-325$ & $\begin{array}{r}26 \\
5\end{array}$ & \pm & $\begin{array}{l}\mathbf{N} \\
\mathbf{N}\end{array}$ & $\begin{array}{l}\mathbf{N} \\
\mathbf{N}\end{array}$ & $\begin{array}{l}10 \\
10\end{array}$ & $\begin{array}{r}1 \\
1.5\end{array}$ & $\begin{array}{l}\mathbf{N} \\
\mathbf{N}\end{array}$ & $\begin{array}{r}\mathrm{L} \\
5\end{array}$ & $\begin{array}{l}\mathbf{N} \\
\mathbf{N}\end{array}$ & $\underset{\mathrm{N}}{\mathrm{L}}$ \\
\hline 136 & $70-\mathrm{ASn}-326$ & $\mathbf{5}$ & + & $\mathrm{N}$ & $\mathbf{N}$ & 10 & 2 & $\mathrm{~N}$ & 20 & L & 20 \\
\hline 137 & $70-\mathrm{ASn}-327$ & $\begin{array}{l}2 \\
4 \\
3\end{array}$ & \pm & $\begin{array}{l}\mathbf{N} \\
\mathbf{N}\end{array}$ & $\begin{array}{l}\mathbf{N} \\
\mathbf{N}\end{array}$ & $\begin{array}{l}10 \\
10\end{array}$ & $\begin{array}{l}2 \\
2 \\
2\end{array}$ & $\underset{N}{\mathbf{N}}$ & $\begin{array}{l}20 \\
15 \\
10\end{array}$ & $\underset{\mathrm{L}}{\mathrm{L}}$ & $\begin{array}{l}20 \\
20\end{array}$ \\
\hline \multicolumn{12}{|c|}{ Hannum Creek area } \\
\hline $\begin{array}{r}\mathrm{BAO}-054 \\
067 \\
069\end{array}$ & $\begin{array}{l}\text { 70-ASn-338 } \\
70-A \text { Sn }-339 \\
70-A S n-340\end{array}$ & $\begin{array}{r}9 \\
11 \\
9\end{array}$ & $\begin{array}{l}(5) \\
(5) \\
(5)\end{array}$ & $\begin{array}{r}0.5 \\
.7 \\
.7\end{array}$ & $\begin{array}{l}\mathbf{N} \\
\mathbf{N}\end{array}$ & $\begin{array}{l}\text { ND } \\
\text { ND } \\
\text { ND }\end{array}$ & $\begin{array}{r}2 \\
1.5 \\
2\end{array}$ & $\begin{array}{l}\mathbf{N} \\
\mathbf{N} \\
\mathrm{N}\end{array}$ & $\begin{array}{l}150 \\
150 \\
150\end{array}$ & $\begin{array}{l}\mathrm{L} \\
\mathbf{N} \\
\mathrm{L}\end{array}$ & $\begin{array}{r}150 \\
700 \\
2,000\end{array}$ \\
\hline
\end{tabular}

$1+$, plus-40-mesh fraction : - , minus-40-mesh fraction.

3 Analyst R. L. Miller. Detection limit is $200 \mathrm{ppm}$.

3 Determined by wet chemical methods by R. L. Mille:.

4 Analysis by mercury detector by D. G. Murrey.

5 Total sample.

010 percent.

analyzed by semiquantitative spectrographic analysis by Curry. Hamilton analyzed splits of many samples. Mercury was determined by mercury detector by D. G. Murrey, and arsenic and zinc by both colorimetric (wet chemical) and spectrographic methods by R. L. Miller.

The results reported in table 1 illustrate that even the crude prototype samplers were capable of recovering sufficient sample for diverse analyses; major geochemical anomalies involving numerous metals are shown in the soils and stream sediments of the Lost River area and in the soils of the Rapid River area. Moderate anomalies in silver, tin, zinc, and mercury are shown in Dahl Creek, and a strong multimetallic anomaly is shown at Hannum Creek. Stream sediments from the Kuzitrin River contain no metals in anomalous amount, and no mineralized areas are known nearby; mercury is relatively high, but this reflects nearness to the volcanic fields, inasmuch as mercury content of soils along all faults increases as the volcanic area is approached.

Results of sampling in the Quartz Creek area are disappointing, in view of the large anomalies reported by Miller and Elliott 
collected by light aircraft and of check samples collected by hand - Continued

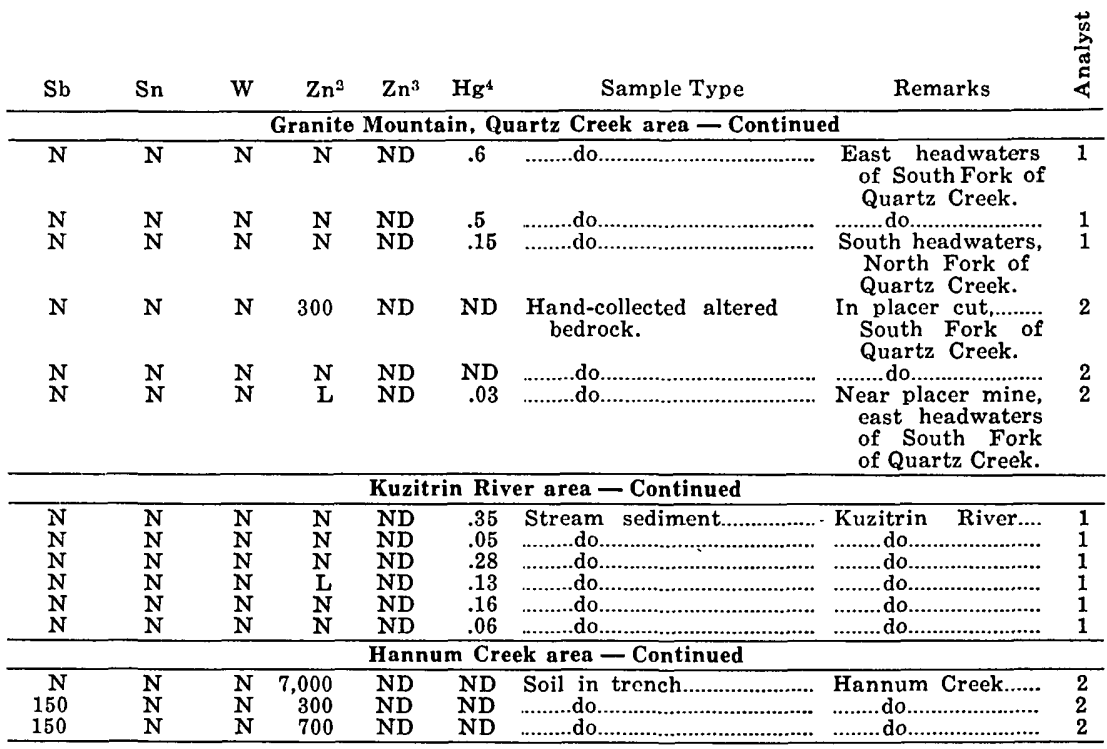

(1969). It is entirely possible that different altered areas were sampled by Super Cub than were sampled previously. Alternatively, not all oxidized and stained areas may be mineralized, and by chance only unmineralized ones were sampled from the air.

The results of the test sampling leave little doubt that the airborne sampling methods are capable of discovering and outlining anomalies in wet soils and stream sediments of diverse areas on the Seward Peninsula. Additional testing will determine whether the methods are universally applicable. Such testing is in progress, and tests to date indicate that modification must be made in devices used in dry soils. Additional modifications will continue to be made as devices are tested in different areas.

\section{COSTS OF SAMPLING}

Because all sampling to date has been to test the feasibility of the sampling methods and because only crude prototype devices were tested, no figures are available regarding costs. However, costs would be determined principally by the flying time per sample, which is determined by the success ratio in retrieving samples and by the spacing of samples. Numerous samples were taken only in the Lost River-Rapid River area, and these were taken by hand-retrieving line with a sampler that required laborious cleaning between each sample. Twenty-seven samples were 
collected along a mineralized fault over an interval of about 10 miles in about 2 hours. This collection time included two landings to secure check samples on foot from the impact holes made by the sampler. Inasmuch as approximately 45 minutes were spent on the ground, the sampling rate was approximately one sample in 3 minutes. At least 80 percent of this time was spent in retrieving the sampler and cleaning it. The success ratio was excellent every drop into soil which was wet, or at least damp, was successful. Three drops of the soil sampler were required to retrieve a sample from the Bessie-Maple prospect, which consisted of loose rock fragments. With the more sophisticated samplers shown in figure 7, two people in the aircraft, and a battery-powered winch, samples could be taken at a rate of about one per minute where numerous samples were to be collected in a small area. Normally, the sample spacing will determine the time required per sample.

Sampling with the sand scoop, using the short jointed rods initially employed, required two people and a minimum of about 2 minutes per sample. The success rate was only 50 percent in initial trials, but practice should quickly increase it to over 90 percent. Use of longer sections of rods, with quick-change adaptations, would materially shorten the sampling time. A device is being made such that a sample bag can be placed behind the scoop without drawing the scoop into the aircraft with each sample. If successful, sampling time will be materially reduced.

In a planned geochemical exploration program, diverse sampling devices would be used, and it would seem realistic to average at least one sample in 3 minutes.

No devices have been tested from a helicopter although they have been tested by dropping them from a balcony into sand and soil. Sainsbury's previous experience in sampling soils and stream sediments by helicopter indicates that where a landing was made at each locality, an estimated 20-30 percent of the total flying time can be saved, and samples can be collected from areas not otherwise amenable to sampling without time-consuming foot traverses.

Impact holes are clearly visible from the air and ground. If it were desirable to mark each individual impact area for future inspection, a small weight with a number and a short piece of fluorescent tape (or a bag of dye) could be attached to the sampler with a material, such as masking tape, which would break on impact and thus leave the weight to mark the spot.

\section{CONCLUSIONS}

Geologic mapping and sampling by light aircraft is feasible and cheap. When combined with the use of the sampling devices de- 
scribed, rapid geologic and geochemical surveys can be carried out from light aircraft with substantial savings over conventional methods. When devices are adapted to helicopter use, greater economy and flexibility in geochemical sampling result.

On the basis of the senior author's experience in geologic mapping on foot, by tracked vehicle, and by aircraft and helicopter, an ideal mapping-sampling program is proposed. Initially, the geologist-pilot maps the area entirely by light aircraft (with ground checks and traverses where feasible landing areas exist), locates areas of potential mineral deposits, and collects reconnaissance soil, rock, and stream sediments to check potentially mineralized areas. After about 1 month's lead-off time, a helicopter and a second geologist are brought in, and spot ground checks are made to refine the geologic map, and areas with mineral potential are sampled in more detail. A dependable geologic and geochemical map could be made at a fraction of the cost now involved in such work. The more remote the area, the greater the cost advantage of the techniques.

Study of aerial photographs prior to airborne mapping would be valuable in locating faults and structural complexity. However, the field sheets can be compiled from the air at a rate approximating the time that would be required to study the aerial photographs.

Secondary advantages of a light aircraft are, at times, of great importance:

1. Scintillation surveys are practical with a hand-held counter, for the aircraft may be flown as close to the ground as ground cover allows - for example, about 20 feet.

2. Low-cost mobility allows the geologist to select work areas according to favorable weather, for in the far north, especially, storms and cold north winds often can be avoided by a 50- to 100-mile flight from a main base camp.

3. Helicopter ferry time for fuel caches, and for personnel, is lessened by using a light aircraft to cache fuel.

4. An added safety factor accrues to the isolated camp, for emergency transportation is always on hand.

These secondary advantages need not be considered in planning a nuapping and sampling program as proposed herein.

Although the senior author utilized a Super Cub, any other aircraft which is categorized as short take-off and landing (STOL) would be suitable, the prime requisites being low stall speed, high maneuverability, and low operating costs.

Other uses of the technique, pointed out by various colleagues, are: 
1. Sampling of large areas, such as the Great Plains, for agricultural, pollution, or trace-elements studies.

2. Sampling of snows, windblown dust, and fallen rain waters for many different purposes.

3. Sampling of stream waters for suspended-sediment studies; sampling of water from wide areas so quickly that water quality could be compared under reasonably static conditions.

4. Sampling of soils in conjunction with the airborne mercury detector in the vicinity of mercury anomalies detected in the air.

5. Sampling of vegetation, in conjunction with infrared photography, or doing geobotanical exploration:

Other applications of the methods herein described undoubtedly will occur to other workers in different technical fields.

\section{REFERENCES CITED}

Asher, R. R., 1970, Geology and geochemistry of the Belt Creek-Libby River area, Seward Peninsula, Alaska: Alaska Div. Mines and Geology, Geochem. Rept. 22, 26 p.

Herreid, Gordon, 1966, The geology and geochemistry of the Inmachuk River map area, Seward Peninsula, Alaska: Alaska Div. Mines and Geology, Geol. Rept. 23, 25 p.

Miller, T. P., and Elliott, R. L., 1969, Metalliferous deposits near Granite Mountain, eastern Seward Peninsula, Alaska: U.S. Geol. Survey Circ. $614,19 \mathrm{p}$.

Sainsbury, C. L., 1969, Geology and ore deposits of the central York Mountains, western Seward Peninsula, Alaska: U.S. Geol. Survey Bull. 1287, $101 \mathrm{p}$.

Sainsbury, C. L., Hamilton, J. C., and Huffman, Claude, Jr., 1968, Geochemical cycle of selected trace elements in the tin-tungsten-beryllium district, western Seward Peninsula, Alaska - a reconnaissance study: U.S. Geol. Survey Bull. 1242-F, 42 p. 